\title{
Strategic and Operational Management of Supplier Involvement in New Product Development: a Contingency Perspective
}

\author{
Ferrie E.A. van Echtelt, Finn Wynstra and Arjan J. van Weele
}

\begin{tabular}{|l|l|}
\hline \multicolumn{2}{|l|}{ ERIM REPORT SERIES RESEARCH IN MANAGEMENT } \\
\hline ERIM Report Series reference number & ERS-2007-040-LIS \\
\hline Publication & June 2007 \\
\hline Number of pages & 45 \\
\hline Persistent paper URL & \\
\hline Email address corresponding author & fwynstra@rsm.nl \\
\hline Address & Erasmus Research Institute of Management (ERIM) \\
& RSM Erasmus University / Erasmus School of Economics \\
& Erasmus Universiteit Rotterdam \\
& P.O.Box 1738 \\
& 3000 DR Rotterdam, The Netherlands \\
& Phone: $\quad+31104081182$ \\
& Fax: $\quad+31104089640$ \\
& Email: info@erim.eur.nl \\
& Internet: $\quad$ www.erim.eur.nl \\
\hline
\end{tabular}

Bibliographic data and classifications of all the ERIM reports are also available on the ERIM website: www.erim.eur.nl 


\section{ERASMUS RESEARCH INSTITUTE OF MANAGEMENT}

\section{REPORT SERIES}

\section{RESEARCH IN MANAGEMENT}

\begin{tabular}{|c|c|}
\hline \multicolumn{2}{|c|}{ ABSTRACT AND KEYWORDS } \\
\hline Abstract & $\begin{array}{l}\text { This paper examines how firms succeed to leverage supplier involvement in product } \\
\text { development. The paper extends earlier work on managing supplier involvement by providing an } \\
\text { integrated analysis of results, processes and conditions both at the level of individual } \\
\text { development projects and the overall firm. Following a multiple-case study approach with } \\
\text { theoretical sampling, the study is carried out by examining eight projects in which four } \\
\text { manufacturers from different industries involve multiple suppliers. The findings suggest that } \\
\text { successful supplier involvement is dependent on the coordinated design, execution and } \\
\text { evaluation of strategic, long-term processes and operational, short-term management processes } \\
\text { and the presence of enabling factors such as a cross-functional oriented organization. The } \\
\text { required intensity of these processes and enablers depends on contingencies such as firm size } \\
\text { and environmental uncertainty. In contrast with previous research, we find no indications that } \\
\text { managing supplier involvement requires a different approach in highly innovative projects } \\
\text { compared to less innovative projects. }\end{array}$ \\
\hline Free Keywords & new product development, innovation, R\&D management, supplier relations, purchasing \\
\hline Availability & $\begin{array}{l}\text { The ERIM Report Series is distributed through the following platforms: } \\
\text { Academic Repository at Erasmus University (DEAR), DEAR ERIM Series Portal } \\
\text { Social Science Research Network (SSRN), SSRN ERIM Series Webpage } \\
\text { Research Papers in Economics (REPEC), REPEC ERIM Series Webpage }\end{array}$ \\
\hline Classifications & $\begin{array}{l}\text { The electronic versions of the papers in the ERIM report Series contain bibliographic metadata } \\
\text { by the following classification systems: } \\
\text { Library of Congress Classification, (LCC) LCC Webpage } \\
\text { Journal of Economic Literature, (JEL), JEL Webpage } \\
\text { ACM Computing Classification System CCS Webpage } \\
\text { Inspec Classification scheme (ICS), ICS Webpage }\end{array}$ \\
\hline
\end{tabular}




\title{
Strategic and operational management of supplier involvement in new product development: a contingency perspective
}

\author{
Ferrie E.A. van Echtelt*, Finn Wynstra ${ }^{* *}{ }^{1}$, Arjan J. van Weele***
}

*Eindhoven Centre for Innovation Studies, Eindhoven University of Technology

** Erasmus Research Institute for Management, RSM Erasmus University

* Centrica, United Kingdom

** Erasmus Research Institute of Management, RSM Erasmus University, Netherlands

*** Eindhoven Centre for Innovation Studies, Eindhoven University of Technology, Netherlands

${ }^{1}$ Corresponding author: Finn Wynstra, RSM Erasmus University, PO Box 1738, 3000 DR Rotterdam, Netherlands, Tel +31 (0)10 4081990, Fax +31 (0)10 4089014, Email: fwynstra@rsm.nl.

\section{Acknowledgments:}

The authors gratefully acknowledge the financial support of Océ

and the Dutch Association of Purchasing Management (NEVI) and the support of Wendy van der Valk in the field research, and thank the anonymous reviewers for their detailed and constructive comments.

This paper has been accepted for publication in

IEEE Transactions on Engineering Management

January 2007 


\title{
Strategic and operational management of supplier involvement in new product development: a contingency perspective
}

\begin{abstract}
This paper examines how firms succeed to leverage supplier involvement in product development. The paper extends earlier work on managing supplier involvement by providing an integrated analysis of results, processes and conditions both at the level of individual development projects and the overall firm. Following a multiple-case study approach with theoretical sampling, the study is carried out by examining eight projects in which four manufacturers from different industries involve multiple suppliers. The findings suggest that successful supplier involvement is dependent on the coordinated design, execution and evaluation of strategic, long-term processes and operational, short-term management processes and the presence of enabling factors such as a cross-functional oriented organization. The required intensity of these processes and enablers depends on contingencies such as firm size and environmental uncertainty. In contrast with previous research, we find no indications that managing supplier involvement requires a different approach in highly innovative projects compared to less innovative projects.
\end{abstract}

Key words: new product development; innovation; R\&D management, supplier relations; purchasing. 


\section{Supplier involvement in product development: gaps in literature}

Product development has become an increasingly important strategy for developing and maintaining a strong position in an ever more competitive business arena [1],[2]. Earlier and more extensive involvement of suppliers in product development is arguably one of the ways to help improve product development performance in terms of costs, speed and product quality and can also provide a source of innovative ideas and critical technologies [3]-[7]. Various studies, however, have found that supplier involvement is not always effective and/or efficient [8],[9],[29],[30]. These seemingly conflicting results can be explained, in our view, by three gaps in existing research.

First, much of the current literature focuses exclusively on the involvement of suppliers in individual development projects [4],[7],[8],[10],[11]. Such studies have, among others, contributed to the body of knowledge by investigating the differentiation among supplier roles and appropriate coordination mechanisms [12]-[14]. However, most studies fail to examine how the involvement of suppliers in specific projects is embedded within more long term, strategic processes, such as technological alignment between supplier and manufacturer [15].

Secondly, little research has sufficiently recognized the organizational capabilities required for managing supplier involvement [10]. Previous research has pointed to, for example, the facilitating or enabling role of the organization of the purchasing function [16] and the importance of adequate human resources [17]-[19]. However, few studies have looked in great detail into these and other pre-conditions.

A third area that has received relatively little attention relates to the contextual factors affecting the impact of supplier involvement on performance. To this point, Eisenhardt and Tabrizi [21] found that supplier involvement only accelerated product development in mature computer industry segments. Based on these results, these authors argue that supplier involvement is not an approach that can or should be universally applied. Other arguments in support of this view point to risks such as the loss of proprietary knowledge, the loss of skills crucial for future product development, the danger of getting locked into a supplier's technology, increased management costs and the chance of incommensurable objectives between two collaborating partners [22]-[26].

In conclusion, a fragmented view on managing supplier involvement in product development dominates in most research. Most contributions fail to provide an integral perspective on how companies can benefit from supplier involvement, addressing both project-related and strategic prerequisites and contingencies. For this reason, the aim of this 
paper is three-fold. First, it investigates in detail the critical processes in managing supplier involvement. Secondly, it identifies and analyzes the organizational pre-conditions that facilitate the execution of these processes. Finally, the paper studies the contingencies that drive the need for managing supplier involvement.

In doing so, we use an existing framework for analyzing supplier involvement. This paper applies this framework in studying eight different product development projects at four companies, operating in different industries. By comparing supplier involvement in different firm contexts, our study aims to contribute to a better understanding of the dynamics and requirements for managing collaborations in the area of new product development with suppliers effectively.

The paper is organized as follows. In Section 2, the analysis framework and its origins are discussed. In Section 3, we present the research design and methodology and in Section 4, the results of the eight case studies are presented and analyzed. In Section 5, we discuss and interpret the findings. Section 6 concludes the paper by reviewing the main insights and contributions to research and practice and by discussing the limits and opportunities for future research.

\section{Analysis framework}

Few studies that have reported on supplier involvement in new product development have provided an integrated perspective on managing supplier involvement in terms of decision-making, communication and coordination processes. Studies by Ragatz et al. [6], Takeishi [10], Evans and Jukes [56], and Dowlatshahi [60] have all identified a number of such processes, but their focus is primarily on short-term project activities. Therefore, we have chosen a framework that originally was developed by Wynstra et al. [15],[16],[27] and which later was extended by Van Echtelt et al. [28]. This framework argues that one of the main factors in achieving successful involvement of suppliers in new product development is related to the coherence between how a firm deals with supplier involvement on a (development) project basis, and how it in parallel deals with more strategic and long-term processes.

Grounded in resource dependency theory, the framework has been subsequently refined in two series of exploratory case studies [15]. These case studies resulted in a set of some 20 activities that contribute to the effective and efficient supplier involvement in product development. A third series of explanatory case studies was aimed at identifying the impact of external and internal conditions that facilitate the execution of these activities 
('enablers') and conditions that require a more intensive execution of these activities ('drivers') [16].

A follow-up study continued this work, consisting of two parts. The first part consisted of a longitudinal, embedded multiple-case study of supplier involvement at one individual manufacturer of copiers and printers [28]. This resulted in a revised framework, distinguishing more clearly between operational, short-term aspects and strategic, long-term aspects - not only regarding the managerial processes for managing supplier involvement, but also regarding the results of that involvement (performance), and the enabling and driving conditions (see Figure 1).

The second part, reported here, consisted of a cross-sectional study of eight new product development projects at four companies in which the revised framework was tested for explanatory power in different industry and firm settings. Before turning to the empirical part of the paper, the framework and its different elements are explained in further detail.

\section{$\underline{\text { Insert Figure } 1 \text { about here }}$}

\section{A. Processes for Managing Supplier Involvement in Product Development}

In the previous study, the analysis of eight supplier-collaborations across six different development projects demonstrated that the success of supplier collaborations could largely be explained by the extent to which the buying firm planned and executed supplier involvement management processes. The study found that it was useful to make a distinction between the Strategic Management arena and the Operational Management arena.

The Strategic Management arena provides long-term, strategic direction and support for project teams adopting supplier involvement. It also contributes to building up a supply base motivated and capable to meet changing technology and capability needs. The Operational Management arena involves planning, managing and evaluating actual collaborations in the context of a specific development project. Both sets of processes are coevolving and interdependent, and none of the individual processes can be said to be generally more important than others.

\section{1) Strategic Management Processes}

The framework comprises a plan-do-check-act cycle of seven strategic management processes, while often in reality the processes will be executed in a more iterative way (see Figure 1). 
In line with existing literature, the framework argues that developing the in/outsourcing policy regarding both technologies and product development activities provides necessary guidance for lower level product development decisions in different departments [35],[36]. Hence, the first process is: 'Determining in/outsourcing policy regarding technologies and new product development activities'. The second process is focusing on the how of supplier involvement: 'Formulating and communicating guidelines/procedures for managing supplier involvement' to relevant departments and suppliers. Such procedures and guidelines could be very formal and restrictive, or more 'open', depending on the circumstances [37],[38].

Next, a motivated and capable supply base must be created and maintained. 'Monitoring supplier markets and current suppliers for relevant developments' therefore includes monitoring technological developments in the markets of the manufacturer and suppliers, and monitoring the capabilities of the current supply base. 'Pre-selecting suppliers for future involvement in new product development' is a fourth key process, involving the pre-qualification of capable suppliers and the compilation of a list of preferred suppliers with relevant innovation-related capabilities from which project teams can choose [39]. It also includes consulting and involving suppliers in advanced development, in order to develop new technologies and parts for application in future product development projects [25],[40].

Furthermore, companies should be 'Exploiting existing supplier skills and (technical) capabilities'. In this process, companies focus on technologies and products already available in supplier markets when designing new products. Alternatively, firms may choose to deploy a stronger 'demand-pull' approach by 'Motivating suppliers to develop specific knowledge or products'. Technology road-mapping can be an effective mechanism to foster and direct supplier investments for future technological cooperation [6].

The final strategic process involves 'Periodically evaluating guidelines and supply base performance', to improve the management of supplier involvement by codifying previous experiences.

\section{2) Operational Management Processes}

According to the framework, a cycle of nine operational management processes is required to foster effective supplier collaboration in a specific product development project.

'Determining desired project-specific develop-or-buy solutions' first involves identifying for which components, modules etc., suppliers are going to be involved in the 
development process. In order to be able to do so, this process requires the definition of functional and physical boundaries and interfaces of the different 'building blocks' [22],[41].

Both activities have a significant influence on the next process, 'Searching for and suggesting alternative technologies, components and suppliers'. This process seeks to increases the solution space for the project team, leveraging the strategic monitoring activities regarding technological developments in supplier markets. The third process, 'Selecting suppliers for involvement in development projects' requires careful analysis of the match between the desired and the available supplier capabilities, to be followed by 'Determining the extent and moment of supplier involvement ${ }^{1}$.

The fifth process concerns 'Determining operational targets and work packages', which is important to prevent misunderstandings, especially in the case of new suppliers [5],[35],[42]. Stipulating contact points and communication procedures, in other words: 'Designing the communication interface with suppliers', has also been found to be a valuable step in preparing for the actual collaboration [42],[43]. This can also be extended to the collaboration with lower tier suppliers.

The actual coordination of development activities aimed at integrating different components, i.e. 'Co-ordinating development activities with suppliers', is especially important in collaborations in which multi-technology and complex parts are developed [13]. 'Evaluating part designs' seeks to balance the trade-offs in terms of the technical and commercial targets to be achieved.

Finally, the framework suggests a ninth process, 'Evaluating/feeding back supplier development performance'. Explicit evaluation moments provide additional learning opportunities for future collaboration episodes by explicitly addressing issues and problems, which have remained under the surface during the collaboration.

\section{B. Enabling Factors Facilitating the Execution of the Management Processes}

In line with the two groups of managerial processes, the framework identifies two types of enabling factors: strategic business unit and operational project enablers. These enablers are primarily to be seen as antecedents that positively affect the management processes, but they can also have a direct positive effect on the results of supplier involvement.

\footnotetext{
${ }^{1}$ The selection of suppliers and determining the extent and moment of involvement are highly interdependent processes. Since varying degrees of involvement require different types of capabilities and organizations,
} 
Strategic Business Unit Enablers describe the overall organizational context of Purchasing and R\&D. In previous literature, a number of structural characteristics have been suggested that indicate that cross-functional integration between Purchasing and R\&D is an important enabling factor. Integration is facilitated, for example, by the presence of a group in the purchasing department which focuses on product development. Another practice that may foster integration is the formal involvement of purchasing staff in the project team [16]. In addition, various authors have considered the following personal factors to be critical conditions for the effective management of supplier involvement: the extent and type of technical experience; the type and level of training/education; and the degree of proactiveness and credibility as perceived by others [16]-[19]. We label these three factors together as 'human resource quality'. Whereas these elements are primarily focused on the qualities of the buyers involved, our previous studies found evidence that the qualities of the R\&D staff involved also matter in relation to their ability to carry out the different managerial activities.

We also found that these organizational characteristics are not sufficient for effective cross-functional collaboration at the level of individual development projects. Therefore, similar factors at the level of the project team have been identified, which we have labeled as 'Operational Project Enablers'. At this level, 'team stability', as prior research has demonstrated, also has a positive impact, as it preserves knowledge about important events earlier in the collaboration [44]-[46].

\section{Driving Factors Affecting the Need for Execution of the Management Processes}

In completing our framework we now discuss the factors that may drive successful supplier involvement. Adopting a general contingency perspective, it is important to understand the possible contingencies that determine how intensively the different managerial processes should be carried out. The driving factors can be seen as moderating variables that negatively affect the (positive) relationship between management processes and results (see Figure 1). In other words; unlike enablers, drivers do not have a direct effect on the extent to which the management processes are performed, but do require more intensive execution of these processes in order to achieve the same level of results.

Analogous to the enabling factors, we propose a distinction between 'Strategic Business Unit Drivers' and 'Operational Project Drivers'. Business unit drivers are factors 
that determine the need for carrying out the strategic processes related to supplier involvement. Several studies identified and investigated particular market and organizational characteristics and their relationship with the adoption of supplier involvement or supporting managerial processes. These include (1) firm size, (2) firm reliance on $R \& D$, (3) firm reliance on its suppliers, (4) firm production type and (5) the technological uncertainty in the firm's competitive environment [11],[16],[21],[47].

We distinguish project driving factors because within the same firm, individual projects may call for a customized approach to supplier involvement related decision-making processes and activities. Based on previous research, we consider the 'degree of project innovation' a strong factor in requiring more intensive execution of operational management processes [6],[61]. To some extent, this factor overlaps with other factors such as project complexity or project size [48]. High degrees of product innovation increase the need for project-related activities and mechanisms that bring in relevant information on technologies early in the development process [32],[52].

\section{Performance}

The results of managing supplier involvement in new product development have been more intensively studied in previous research, albeit in relatively separate streams of literature. In line with the dominant focus of most research on single projects, short-term benefits in terms of development project results have received more attention than long-term, strategic benefits.

Short-term results are commonly related to product quality, product and development cost, and development time at the level of individual parts as well as the entire development project [4],[6],[7],[9],[10],[29]-[31]. Long-term results are usually related to learning benefits [31],[32], access to supplier knowledge [27],[33],[34] and alignment of technology roadmaps [25],[35].

\section{Research design and methodology}

To test this framework's external validity across different industry and firm settings, our field research included a cross-sectional series of case studies of eight new product development projects in four buying firms, each in a different industry. The case studies, conducted in 2002-2003, aimed to analyze the extent of execution of the strategic and 
operational managerial processes and to relate these findings to the short-term and (expected) long-term results of supplier involvement [62].

To enhance external validity, we used theoretical sampling in our selection approach [53],[59]. In theoretical sampling, cases are selected to represent variety on a number of apriori, theoretically defined factors. In that way, cases should produce contrasting results but for predictable reasons, resulting in so-called theoretical replication [53; pp. 46-53]. In our theoretical sampling, we focused on the driving factors, both at the strategic and operational level, as these are relatively easy to assess up-front. Therefore, on the strategic level, firms had to differ in terms of their market, technological and/or structural characteristics (particularly size and production type; see section II.C).

To achieve a spread in different types of development projects (the second level of theoretical replication), each firm was asked to submit two product development projects that differed in terms of the degree of project innovation. Highly innovative projects had to be characterized by a high degree of novelty for the manufacturing firm with regard to the product functionality, architecture or manufacturing technologies used. A project was regarded as being less innovative if it only involved a slight adaptation of a firm's existing product $^{2}$. The projects should have been completed recently ( $<$ six months), as this would allow more reliable measurement of the project-related processes, conditions and results. Note, however, that the recent nature of the projects and the cross-sectional nature of the study imply limitations for the assessment of long-term results, which ideally are assessed on the basis of longitudinal data ${ }^{3}$.

Within each project, the buying firm was asked to identify those suppliers that had played a substantial role in the overall development project. These suppliers would be targeted for additional data collection, to enhance the (construct) validity of our study through (source) triangulation [53].

\section{A. $\quad$ Case Study Background}

The four selected companies were: Philips Domestic Appliances (DAP), PANalytical (PAN), Boon Edam (BED) and HJ Heinz (HJH), all based in the Netherlands (see Table I).

\footnotetext{
${ }^{2}$ Each of the firms first suggested two projects, and these were evaluated by the research team. In one case, we selected another project than the firm originally suggested to make sure there was enough variation between the firm's two projects in terms of project innovativeness.

${ }^{3}$ Given the fact that some projects were indeed only completed very recently, our assessment of the long-term collaboration effects also allowed for “expected” effects (see Table IV). Despite the limitations, we believe that measuring even expected long-term effects is better than excluding them alltogether.
} 
Philips Domestic Appliances (DAP) develops and manufactures personal care products and home appliances (e.g. shavers, coffee machines and vacuum cleaners); a typical mass-assembly operation. The first project concerns the development of a fragrance module for a high-end specialist vacuum cleaner series. The fragrance was developed with the help of a specialized consultancy agency (A). The project is classified as being moderately to highly innovative, considering it involved a highly new functionality introduced to an existing product. The second project involves the redesign of a boiler for a follow-up version of a highly successful and innovative crème coffee machine (Senseo). The project is classified as having a low-to-medium innovative level. In this project, DAP collaborated with a European supplier (B) of heating elements for kettles and coffee machines.

The second firm, PANalytical (PAN), is a large, global analytical instrumentation and software supplier for industrial process control and R\&D applications. The firm offers X-ray analytical equipment for industrial and scientific applications as well as for the semiconductor market, typically produced in units and small series. In the highly innovative 'Spectrometer project', PAN developed a novel system for analyzing samples using a newly developed detection technology. This project was carried out with the help of four suppliers: a detector system supplier (C), a high voltage generator supplier (D), a metal casing and mechatronics assembly supplier (E), and an embedded software board supplier (F). In the low innovative sample changer project, PAN developed a customer-specific system for analyzing a higher capacity of samples than in the standard product. One of the key suppliers $(G)$ in this project was involved in the development of a module to provide the guiding technology and housing of the sample changer.

Boon Edam (BED), a medium-sized firm, is a world market leader in the area of revolving doors and security products for the high-end market (e.g. shopping centers, airports). BED's production is largely unit-based. The first project concerned a high-speed safety-gate, actually derived from a product already manufactured by one of BED's subsidiaries, but a major redesign resulted in a highly innovative product for BED. It was carried out mainly with the help of two suppliers, respectively supplying a sensor-package with a control box $(\mathrm{H})$ and the steel construction (I). In the second, less innovative project, two high capacity revolving doors with different door columns were developed. Two suppliers were involved ( $\mathrm{J}$ and $\mathrm{K}$ ), one for each column type.

HJ Heinz (HJH) is a large multi-national food and beverages firm that develops and produces quick-serve meals and meal solutions. Production is mainly process-based. The first project concerned a ready-to-drink carbonated soda beverage. The drink was developed and 
bottled in collaboration with a Spanish subsidiary of a Dutch filling firm (supplier L). The project was designated as a highly innovative project because of the new combination of manufacturing processes, packaging and product concepts. The second project concerned a new flavor for fruit-flavored sprinkles and was selected as being less innovative (line extension). HJH regarded this project as an outsourcing project and involved a co-packer in product development (supplier M).

\section{$\underline{\text { Insert Table I about here }}$}

\section{B. Data Collection}

Data was collected through a self-administered questionnaire and extensive semistructured interviews with representatives from both the manufacturer and selected suppliers.

Based on our earlier research, we created two complementary sets of questionnaires. The strategic questionnaire, sent to the companies’ purchasing and R\&D managers, dealt with the long-term collaboration results, strategic management processes and the strategic (or firm level) enablers and drivers. The second questionnaire concerned the operational management of, and conditions for, supplier involvement in the context of a specific development project. This questionnaire was sent to the people who were directly involved in the product development project under study, i.e. the project leader and the project purchaser ${ }^{4}$. Like previous studies, our earlier case studies found the Purchasing and R\&D departments to be the most relevant internal actors [31],[52]. For each of the processes, enablers, drivers and results we developed a minimum of two questionnaire items, and often four (see Appendix A). The questionnaires have been jointly developed by a four-person research team, and have been extensively pre-tested ${ }^{5}$.

A case protocol was developed for interviewing face-to-face all people who filled in a questionnaire, to discuss the project history, management processes and conditions in more detail. In this way, the original questionnaire outcomes could be verified and where necessary adjusted on the basis of information from other sources. Moreover, we interviewed the selected suppliers to obtain the counterpart's perspective on the collaboration. At the suppliers, we normally conducted interviews with one person who represented the

\footnotetext{
${ }^{4}$ The companies could propose other key informants if this would be helpful in analyzing the projects.

${ }^{5}$ We approached in total 11 development and purchasing managers and project leaders and buyers from a medical systems and a printer manufacturer. After having completed the questionnaires, they raised several issues regarding the length, wording and scales of the questions. We then discussed and compared the various remarks in the research team and adapted the research instrument.
} 
commercial interface with the customer and with another person involved in technical development. Across the four firms and their suppliers, a total of 45 interviews were conducted (see Appendix B for informant details).

In order to facilitate subsequent analysis, we used Likert scales to summarize the observations on the different elements from the framework. For the managerial processes, a five-point Likert scale, with explicit and distinctive labels, measured the degree of active and systematic execution of the processes. This scale was adapted from an existing instrument for assessing organizational maturity of suppliers [58 ${ }^{6}$. In choosing a three-point scale for assessing the remaining elements of the framework (results, enablers and drivers), we had to make a trade-off between accuracy and efficiency. During the pretest interviews many respondents indicated that five or seven-point scales, especially for the drivers and enablers, were difficult to apply. Overall, in our opinion, having access to multiple informants and qualitative, rich information on the actual situation behind the absolute scores outweighs the disadvantages of using a three-point scale.

The results section contains three groups of results: 1) Short-Term Project Results (STPR), 2) Short-Term Collaboration Results (STCR), and 3) Long-Term Collaboration Results (LTCR). The STPR and the STCR were respectively measured in the light of the overall project and of the specific part development targets. The reason for distinguishing project and collaboration results is that the first focuses on overall project performance, which may only be partly explained by the results of supplier involvement in the project as measured by the latter. The choice for actual-to-target values allowed a comparison between projects from different companies in terms of results. The LTCR were measured in terms of their actual and/or expected occurrence as a result of this collaboration.

\section{Data Analysis}

In preparing the case reports, the scores obtained from the questionnaires were used as starting points and further clarified and substantiated with the qualitative data obtained from the interviews. Discrepancies between the answers of different informants were explored further in the interviews. Remaining inconsistencies were discussed in the research team, followed-up in meetings with the case companies and a final assessment was made after

\footnotetext{
${ }^{6}$ The labels were defined as follows: 1-Absent: the process is not carried out; 2-Reactive: the process is carried out in an ad-hoc way, as a result of occurring events; 3-Pro-active: the process is carried out following an implicit structure or set of activities; 4-Systematic: as in 'pro-active', but supported by systems, procedures and guidelines; 5-Intelligent: as in 'systematic', but able to critically review the processes in light of the situation
} 
careful consideration of all the data ${ }^{7}$. Transcripts were all sent back for verification with the interviewees. All interview transcripts and case reports were discussed in the research team to further enhance the validity of the study.

At each buying firm, we have held at least one in-company presentation in order to obtain feedback on our assessment and the insights generated, also from people that had not been interviewed but participated in the NPD projects we studied. We also organized two plenary meetings during which the findings across the different firms and projects were presented and discussed, to stimulate debate, understanding and mutual learning.

Table II provides an overview of the methods we have used in this study to increase the validity of our findings and to meet the usual criteria for qualitative research [53].

\section{Insert Table II about here}

\section{Case analysis and findings}

To analyze the eight new product development projects, we first undertake an intracase analysis (see Table III), linking the results to the overall patterns in processes, enablers and drivers - both at the operational and the strategic level. This first analysis uses the main and highest possible level of aggregation in our framework by grouping together all operational project drivers, all strategic business unit drivers, all operational project enablers, etc. The scores reported in Table III therefore represent the (straight) averages for the different drivers, enablers, processes and results. Subsequently, we present a more detailed cross-case comparison for the different elements of our framework, in which we will highlight specific results, processes and conditions. All analyses are based on the combined questionnaire and interview data.

\section{$\underline{\text { Insert Table III about here }}$}

and to adapt (incidentally or more permanently) when necessary. Adding these labels to the 5-point Likert scale enables a more reliable assessment of these processes across the different cases.

${ }^{7}$ Both at the strategic and operational level, this meant that - only for the remaining inconsistencies - in case of questions regarding the processes and conditions that had a more commercial character, we regarded the answers of the purchasing representative as leading, whereas for those with a more of a technical character the answers from the $R \& D$ representative were used. Also the outcomes of the supplier interviews were used in the final assessment. In each of the eight cases, such final "weightings” were only done for a few variables from our framework. 


\section{A. Overall patterns}

As a first step in the analysis, we investigate to what extent the general patterns in the eight case studies support our conceptual framework. Hence, we are interested in the correlations between the results and the management processes for the different cases. For that purpose, we group the cases both on the basis of their scores on the results and on the basis of their management activities. Doing that not for individual cases but for groups of cases makes the analysis more robust by making it less vulnerable to incidental outliers. On a more general level, it is an approach that fits better with the advantages and limitations of our primarily qualitative approach.

In line with our conceptual model, we first determine an average score for the combined strategic and operational management processes for each project. We then consider the presence of strategic and operational enablers, and subsequently form three groups of projects in terms of their combined process and enabler scores: a top group (VC, SD, FS), a middle group (CM, SM, SC) and a bottom group (SG, RD). Likewise, we cluster the projects based on their combined short-term and long-term results into a top group (VC, CM, SD), a middle group (FS, SG) and a bottom group (SM, SC, RD). Clearly, these two sets of groups are not entirely consistent. Three of the projects perform as predicted (VC, RD, SD), while the majority of projects perform better (CM, SG) or worse (SC, SM, FS) than predicted. So, at first sight, the cases reported here do not fully support our model ${ }^{8}$.

However, controlling for the presence of driving factors (moderators), the patterns become more consistent with the predictions from our model. Figure 2 maps out how better or worse performance than predicted (solely on the basis of enablers and management processes) is related to the presence of more or less taxing conditions, as represented by the strategic driving factors such as company size (see Appendix A). (Section IV-F looks at the operational project drivers in detail, hence their exclusion here.) Whereas cases in the topright and bottom-left quadrants would strongly refute our predictions, the majority of the cases are on the downward sloping diagonal as our complete model, including the driving factors, would predict. For example, the SM, SC and FS projects score worse than predicted on the basis of enablers and processes, but this can be explained by the strategic driving factors that apparently were more taxing than anticipated by the respective organizations. These findings support the conceptualization of these driving factors as moderating variables.

\footnotetext{
${ }^{8}$ Detailed calculations are available from the authors, but are solely based on the information available in Table III.
} 
Thus, when taking into account firm related contingencies, the extent to which a firm executes the operational and strategic management processes from our framework is strongly related to its performance in manufacturer-supplier collaborative product development. The subsequent sections go into more detail for each of the framework elements.

\section{Insert Figure 2 about here}

\section{B. Performance}

Two projects stand out in terms of their short-term collaboration results: the vacuum cleaner project (DAP) and the carbonated soda drink project (HJH). Also the other projects of these two firms do relatively well, i.e. the coffee machine (DAP) and the fruit sprinkles (HJH) projects, and likewise the sample changer (PAN) and speed gate and revolving door (BED) projects. The worst project, in terms of short term results, is the spectrometer (PAN) project, which predominantly scored below target. For long-term results, the pattern is quite similar, except that the sample-changer and revolving door projects score quite badly.

Focusing on the individual performance aspects (see Table IV, left), an interesting pattern emerges. In seven out of eight projects, the collaborations with suppliers resulted in satisfactory technical performance at the end of the project, or even better. In terms of development costs incurred, the results also show a positive picture. However, interviews revealed that not all relevant development costs were being monitored (e.g. extra coordination costs related to resolving quality problems) and therefore one needs to be careful when interpreting these on-target scores ${ }^{9}$.

In most cases, the overall development project achieved similar performance levels as the collaboration in question. Only for the sample changer (SC) did the overall project perform better, and for the revolving door (RD) worse. When analyzing overall project performance in more detail (Table IV, middle), we notice that, again, quality targets are achieved more often than product cost targets.

Regarding the long-term benefits that companies managed and/or expected to achieve from the various collaborations, we note that again DAP and HJH have the highest scores,

\footnotetext{
${ }^{9}$ The problem of 'unaccounted' development costs basically holds for all firms and projects, but the extent may vary depending on the budget tracking capabilities in each company and the number of design changes in a project. The more coordination and communication is required (as triggered by, e.g. design changes), the more likely the invisible costs are to increase. These hidden costs appear to have been substantial at DAP, vacuum cleaner project; PAN, spectrometer project; and BED, speed gate project.
} 
while BED and PAN (expect to) realize these benefits to a lesser extent (see Table IV, righthand part). Most companies claimed learning experiences in various collaborations to result in improved designs and more efficient coordination and communication between both parties in future collaborations. This benefit is closely followed by collaborations in which the buying firm expected to have better access to the supplier's knowledge in future collaboration. For example, according to the Purchasing Manager at PAN, only actual, intensive collaboration provides insight into a supplier's true technological and organizational capabilities.

As indicated in the Research Design and Methodology section, for those projects that have been completed only recently, the findings on long-term results need be interpreted with considerable care, as the actual effects cannot be assessed yet. Still, these long-term results are interesting to include because they are not fully correlated with the short-term results (observe, for instance, the two PAN projects and the RD project in Table III).

\section{$\underline{\text { Insert Table IV about here }}$}

\section{Operational management processes}

As expected based on the results, HJH involved its suppliers based on a systematic execution of the operational processes, while other projects show a different picture (see Table V). Especially in the spectrometer project, PAN's relatively pro-active operational management of supplier involvement did not prevent problems and below target performance. DAP, while performing at least as well as $\mathrm{HJH}$, is slightly less pro-active than PAN in operational processes. BED scored the lowest on the operational management processes, but it achieved most of its targets. These patterns suggest that, in line with our conceptual framework, operational management alone does not explain successful supplier involvement ${ }^{10}$. As a partial explanation, we noted already that some of the (development cost) results may be inflated. Further explanations may be found in the pattern of strategic processes and enabling pre-conditions, as analyzed below.

Focusing on individual operational processes, we find that HJH was consciously trying to be explicit about the domain of collaboration and was assessing the technical, commercial and financial risks internally and in its relationships with potential suppliers. HJH spent much time on discussing the content of the work package and targets with the 
supplier, also after the supplier was selected. This strongly contributed to the success of the projects studied in this company.

'Selecting suppliers' often received a low score, because in some of the collaborations suppliers were already known and available. However, cross-functional teamwork in supplier selection appears an important element for identifying potential technical and business risks at an early stage, even in case of an existing supplier (DAP, PAN). Projects of these firms also scored low on determining the extent of supplier involvement and defining the work package and targets with the supplier, which results in ambiguous roles of the parties involved.

Furthermore, informants stressed the importance of having one spokesperson on both sides. Being able to adjust and decide upon an appropriate communication interface when signals emerge that communication does not work, is critical in maintaining development speed. Moreover, this helps to curb irritation during the collaboration. This practice was particularly visible at $\mathrm{HJH}$, where the purchasing department closely monitored the collaboration, and to some extent at DAP and PAN.

Most companies carry out an explicit evaluation of technical design aspects and also evaluate commercial aspects. At BED, being a relatively small company, this occurred in a pragmatic and informal way. Few companies, however, evaluated development performance together with suppliers.

\section{Insert Table V about here}

\section{Strategic Management}

Our framework suggests that a firm that has invested in a strategic management infrastructure is able to select and set up their projects and collaborations quickly and effectively. Such firms will also be able to capture additional long-term and strategic benefits from supplier involvement.

The overall scores on the Strategic Management Processes indicate that two companies were particularly active (Table V, lower part). On average, HJH scored between systematic and intelligent in the strategic management area, whereas DAP scored somewhat lower (pro-active/systematic) but was still at least pro-active in all related processes. PAN was clearly trying to be pro-active in its supplier involvement approach, but was not yet

\footnotetext{
${ }^{10}$ When performing a cluster analysis for overall results vs. only operational management processes, only 2 out
} 
consistently systematic across all technology and product areas. BED was predominantly reactive.

In terms of the actual support derived from these strategic processes for the operational projects, we found that HJH particularly benefited from its strategic efforts in developing a competent supply base for involvement in product development. In the carbonated soda drink project, it had established contacts and identified a collaboration opportunity with one of the supplier's subsidiaries using a cross-functional pre-qualification approach. Likewise, in the fruit sprinkles project, the project team was able to go through the selection process quickly and effectively. At DAP, the coffee machine project team benefited from already having one preferred supplier in the boiler technology area, requiring little effort in selecting suppliers and determining the extent of involvement. However, unexpected demand created a need for a second source of supply, which had not been accommodated for by its strategic pre-selection processes. DAP had to respond to this during the project. PAN's sample changer project team benefited from earlier efforts to build a long-term collaboration with a motivated supplier. However, it was not entirely clear at the outset what development and assembly-related activities would be done internally or externally.

In several other cases, project teams were not able to benefit from a technology that had been pre-developed or from pre-selected suppliers. In contrast to its usual habit, DAP had to develop the new fragrance module within the vacuum cleaner project. PAN had to go through great efforts in selecting and qualifying the supplier for the generator technology. Moreover, it had to improvise in selecting a supplier for involvement in the software development, as a result of an unexpected knowledge and capacity shortage. Although BED had been building up a supply base for production activities rather than for collaborative innovation, BED did not experience serious problems in the revolving door project. This paradox is explored further below, in discussing the driving factors.

To what extent then are the Strategic Management Processes associated with prospects of capturing specific long-term benefits from their collaborations with suppliers? HJH and DAP appear to be generally better equipped to capture the long-term benefits than the other companies. The HJH cases demonstrate that the company displays a systematic care and attention for continuous learning and adaptations of decision-making processes related to supplier involvement. We specifically observe that, compared to other companies, HJH 
scored substantially higher on the evaluation of guidelines and the supply base, and on the evaluation of the development performance of suppliers within projects. HJH's evaluation practices at the strategic and operational project level ensure that learning experiences are made explicit and can be taken on board as action points for future collaborations. By evaluating its guidelines, $\mathrm{HJH}$ is able to transfer some of its local experiences and knowledge into helpful ways of working that are also helpful for other projects. Finally, the evaluation of the fit of the supply base with the overall technology and product development outsourcing policy is strongly emphasized by the purchasing department and receives support from different managers involved in product development and dealing with suppliers.

At DAP and PAN, joint evaluations with suppliers did not take place immediately after the project was finished, nor were future projects immediately identified. This reduces the chance of capturing the learning benefits in future collaborations. DAP is clearly working on developing and applying guidelines for improving the communication and the role of suppliers, and this should be beneficial to future collaborations. Finally, BED does not appear to have an extensive strategy for increased supplier involvement, which may be critical in the view of new products that increasingly depend on electronics and software related technologies.

In conclusion, based upon these case studies, the degree to which the long-term benefits from supplier involvement are achieved seems to be strongly related to the degree to which people have developed coherent routines in executing the various strategic processes. In particular, processes such as proactively identifying the relevant areas for collaboration and pre-qualifying a supply base with specific technological and product development capabilities provide fundamental starting points for the alignment of supplier development capabilities. Furthermore, necessary adjustments to the supply base and to the ways of coordinating collaboration appear to be supported by routinely evaluating the supply base performance and codifying learning experiences into practical guidelines.

Still, the combined long-term and short-term results of supplier involvement in our different case studies cannot be adequately explained by the combination of both operational and strategic management processes. In fact, just adding the strategic processes does not increase the overall explanatory power of our framework ${ }^{11}$. Thus, we need to also investigate enabling and driving factors. 


\section{E. Enabling Factors}

At the level of strategic enablers, we found that especially $\mathrm{HJH}$ has been investing in cross-functional integration, trying to secure the participation of the purchasing department in product development and in strategic decision-making (Table VI). At HJH, multiple internal functions (including Marketing) are official counterparts to $R \& D$ in discussing the input and issues in different types of collaborations with suppliers. At DAP and PAN, there is a formal cross-functional organization which integrates R\&D, Purchasing and Operations. In contrast, at BED we observe that there is no structure that supports early and extensive integration of these departments.

At the level of the actual cross-functional integration at team level in projects, we observed generally lower scores across all companies. At HJH, we note that visible crossfunctional integration is not only a matter of designing a structure but is the result of investing years in creating conviction and trust among key players. At PAN, however, early involvement of the purchasing and manufacturing departments in the project teams did not guarantee a proper risk assessment for all planned collaborations in the spectrometer project. At BED, Purchasing did not provide significant contributions during development and engineering, apart from contract price negotiations and support in communication during production preparation and regular production.

The quality of human resources at both organizational and team level generally scored highest at HJH followed by DAP and PAN, with the lowest score at BED. All companies, except BED, had representatives with higher education, not only in R\&D but also in Purchasing. Job rotations of buyers or R\&D people to other departments, however, are not common practice. At the team level, the projects at HJH benefited from a higher degree of commercial and technical skills for Purchasing and R\&D representatives (and for the other functions involved) compared to other projects. In the case of BED, limited technical knowhow and educational background of newly recruited buyers played a critical role in reducing their credibility. This undermined the acceptance of suggestions and the mutual identification and understanding of development risks.

Despite these observations that generally seem to fit our framework, the pattern in the performance of the different projects cannot be fully explained by the combined pattern in management processes and enablers (see IV.A), even though it is a (marginally) superior explanation than just looking at operational management processes or a combination of

\footnotetext{
${ }^{11}$ When performing a cluster analysis for overall results vs. combined strategic and operational management
} 
operational and strategic management processes (see IV.C and D). Hence, we need to turn to firm and project contingencies.

\section{$\underline{\text { Insert Table VI about here }}$}

\section{F. $\quad$ Driving Factors}

Our basic proposition is that high scores on driving factors require more pro-active, systematic and intelligent management processes to mitigate the increased risk and complexity.

This proposition is supported by the data from our cases as far as the strategic business unit drivers are concerned (see IV.A). When analyzing these strategic drivers in more detail, we find some indication that firm size variations specifically point to differences in the need for explicit guidelines. BED, a relatively small firm, adopted fewer explicit and formal guidelines for supplier involvement and still met most of its short-term objectives. At small firms, informal communication may suffice [34]. General management, but also purchasing and $R \& D$ management, for instance, may be able to convey their objectives and preferred approaches in personal communications with all of those involved in supplier involvement. In the other, larger companies usually with larger departments and more hierarchical levels, policies and guidelines are a more effective binding element in the process of involving and improving the management of suppliers in product development.

In general, large firms would need to invest more in strategic processes in order to capture the potential synergy of the lessons learned in individual projects and to maintain a consistent approach towards its suppliers. In smaller firms, this synergy and consistency which ultimately contribute to efficient and effective supplier involvement - may be achieved more simply in the daily operations, primarily because there are fewer people that meet relatively more often and thus more easily exchange information and ideas.

Secondly, the degree of technological uncertainty appears to affect the need for particular management processes. The high electronics content and complex technologies in the products of PAN (and to some extent DAP) demand an organization that is able to spot and to integrate the new technologies and to manage the transition to new technologies. Firms facing high technological uncertainty require more market research, and more (frequent) analysis of in-/outsourcing decisions.

processes, again only 2 out of 8 cases follow the predicted pattern. 
At the operational project level, the key driver according to previous research is the degree of innovativeness [6],[61]. However, Table VII demonstrates no clear patterns in the extent of operational management processes being carried out in relation to the degree of innovativeness. Does this mean that highly innovative projects are "not getting the attention they deserve"? Apparently not; looking at the short-term project results reported in Table VII, we see little difference between highly and low innovative projects. Hence, even controlling for performance, we cannot find a clear relation between the level of innovativeness of a project and the extent to which operational processes are being carried out.

Therefore, we specifically investigated to what extent companies planned and prepared supplier involvement in the different projects. Previous research has specifically argued that in highly innovative projects, supplier involvement cannot be planned very well [21]. Thus, we would expect less pronounced operational planning activities in the more innovative projects. We therefore made an exclusive comparison for the different projects of only the operational planning processes (OMP 1-6).

Again, however, we find no strong indication that in this respect, firms manage their highly innovative projects differently from how they manage projects that are less innovative. In highly innovative projects, the planning processes score even higher compared to low innovative projects (at PAN and BED) or the same or only slightly lower (at DAP and HJH). Hence, contrary to our proposition, there seems to exist no clear relationship between the level of project innovativeness and the required extent of executing operational management processes $^{12}$.

\section{$\underline{\text { Insert Table VII about here }}$}

\section{Discussion}

The alternative analyses presented above provide strong indications that business unit characteristics represent highly relevant conditions to consider when managing supplier involvement. Including these strategic business unit drivers in our conceptual framework adds to its explanatory power, compared to a framework only comprising processes and enablers to explain supplier involvement results.

\footnotetext{
${ }^{12}$ An alternative way to demonstrate the lack of explanatory power of the degree of project innovation is to include the scores on 'operational project drivers' in the assessment of 'taxing conditions' (Figure 2). Doing so,
} 
Our findings do not support the notion that project characteristics represent highly relevant conditions for managing supplier involvement. In our case studies, project innovativeness would not lead to the need for a differentiated approach in setting up supplier collaboration in new product development. This contradicts findings in other studies that higher degrees of technological uncertainty would increase the need for project-related supplier management activities [6].

It seems unlikely that our findings are the consequence of the design of the study, in which we did not conduct absolute measurements related to the degree of innovativeness of the different projects across the different firms. As in many studies, we have primarily relied on the informants' perceptions of the degree of innovativeness or newness in relation to aspects such as the individual elements and overall architecture of the product (see Appendix A) $[48],[63]^{13}$.

A more likely explanation for not finding clear relations in this study could be that relations between the degree of innovation and the extent of process execution are not salient at the level of the overall NPD project, but only at the level of individual suppliers. One possible avenue for investigating the impact of innovativeness on required management processes in more detail is thus to move the analysis to the level of individual supplier collaborations within a given project. Collaborations concerning the development of highly novel and complex parts require different coordination and communication interfaces than simple and standard parts [42],[43]. Hence, factors such as the technical complexity and novelty of the part mainly affect the processes that are specific to the collaboration with an individual supplier.

It seems therefore logical that successful firms are managing supplier involvement not only at the strategic and overall project level but also at the level of collaboration with individual suppliers. Based on this insight, one suggested adaptation to our initial framework would be to introduce a third, 'collaboration' level of analysis. According to this extended model, effective supplier involvement requires management in three arenas. Besides the strategic and project based management of suppliers, the management of collaborations with individual suppliers would require a specific set of processes that are extensions of the processes at the project and strategic level. Distinguishing three different, though interrelated,

would result in the SG, VC, FS and SC cases moving away from the downward sloping diagonal. In other words, including project innovativeness decreases the explanatory power of our framework.

${ }^{13}$ Our post-selection appraisal of the suggested projects regarding this aspect (see footnote 3 ) focused primarily on the spread in innovativeness between the projects within each firm. 
managerial arenas would further improve our ability to study and better understand the management of supplier involvement.

On reflection, a subset of the Operational Management Processes appears to be highly collaboration-specific: determining operational targets and work package (OMP5), designing communication interfaces (OMP6) and coordinating development activities (OMP7). Other processes, such as determining the extent and moment of supplier involvement, are normally done at the overall project level to address interdependencies between various suppliers and their components.

The proposed extended framework should also include a set of contextual factors at the collaboration level that affect the need for structuring and management of the collaboration. This could then include factors such as component complexity and novelty [13].

Finally, in such a 'three-level' framework, collaboration enablers are those factors supporting the direct collaboration between buyer and supplier. Based on the literature review and previous case studies, various types of 'suppliers' capabilities' appear important when involving suppliers in product development, such as 'technical capabilities' [54],[55], 'project management capabilities' or the supplier's 'costing capabilities'. Collaboration is also fostered by creating a 'compatible culture and operating style' between the customer and supplier [21],[56].

\section{Conclusions and implications}

The objective of this paper has been to derive a validated framework of critical processes and conditions for managing supplier involvement in product development in such a way that both short- and long-term benefits are created. This was done through an in-depth empirical validation of an existing framework in multiple firm and project contexts, resulting in four main findings.

First, the combined long-term and short-term results of supplier involvement cannot be adequately explained by the pattern of operational processes, nor by the pattern of the combined operational and strategic management processes. While the lack of explanatory power of only operational processes is as expected and indeed one of the central notions behind the conceptual framework, the findings regarding strategic management processes are surprising. Perhaps, in our sample of case studies, these findings may be explained by the fact that there were some projects that did not really fit the normal project portfolio of the 
respective firms, for examples in terms of technologies and suppliers used. In such cases, the actual support that projects and their teams may derive from the strategic processes may be more limited.

At the level of individual processes, however, one can clearly indicate particular beneficial effects, and there appears to be also a strong relation between the extent to which strategic management processes are being carried out and the long term results of supplier involvement. For example, one of the most direct contributors to effective operational management came from having pre-selected suppliers for involvement in product development.

The second main finding is that adding strategic and operational factors enabling the execution of the respective management processes only marginally increased the explanatory power of our framework. This would seem to suggest that their effect on the results of supplier involvement is only indirect, via the management processes, and not direct as well.

Thirdly, our study has found very little variation in the way firms effectively manage projects of differing degrees of innovation. This finding contradicts findings from earlier studies, which suggests that further research is required in this area. One suggested explanation may be that differentiation of managing supplier involvement in this respect does not occur at the level of the project, but rather at the level of the individual supplier. The introduction of a set of collaboration management processes besides the operational project and long-term strategic processes would acknowledge the importance of differentiating among individual suppliers. When properly executed, the combination of strategic, projectrelated and supplier-specific processes enable a firm to explore and to integrate existing and new suppliers' resources (e.g. know-how, technologies, relations to third parties) in product development.

The fourth and perhaps most important finding, however, is that the overall pattern encountered in the case studies provides substantial support for our framework when the moderating effect of the driving factors at the strategic level is considered. Firm size appears to be a strong indicator for the increased need for strategic management processes especially the development and communication of guidelines). Furthermore, changing technological or market conditions suggest the need for a more proactive and strategic approach to supplier involvement. Certainly, when a firm's strategy is aimed at substantially increasing levels of supplier involvement, a sustained effort is required to develop a qualified supply base. 
One of the main limitations of our study may be found in the framework's main focus on the entire set of strategic and operational management processes. Although we have considered specific examples of individual processes, we have not designed our study to analyze individual processes and their specific antecedents (enablers and drivers), their interrelationships and consequences (results) across all cases. Subsequent research could investigate these relations on the level of individual processes, and also examine possible synergies and negative interactions among specific processes, and among and between particular drivers and enablers. These studies could either take the form of quantitative surveys or, if one would be more interested in the process of these interactions, multiple-case studies which have been sampled to specifically account for variations in how certain individual processes are carried out. Longitudinal case studies could also better take into account the joint collaboration history of buyers and suppliers as a factor that supports further collaboration [32].

In addition, we have limited ourselves to identifying the critical decision-making activities and conditions from an intra- and inter-organizational perspective. However, supplier involvement does not take place within simple dyadic buyer-supplier relations; it is often affected by other relations of both the buyer and the supplier [3],[41]. Hence, future studies on supplier involvement could address in more detail the issues of managing interdependent relationships - both at the collaboration, project and the strategic level [43],[57].

Further research could also address the change processes in these companies that allow buyer and supplier to improve their collaboration in product development [56]. What are the appropriate informal and formal mechanisms that enable effective learning across different departments and with suppliers, in the context of increasing supplier involvement in product development?

Acknowledging its limitations, we expect that our study has contributed in providing some fruitful foundations and challenging ideas for studying these and other questions in this fascinating and ever more important domain of supplier involvement in product development.

\section{References}

[1] S.L. Brown and K.M. Eisenhardt, "Product development past research, present findings,

and future directions”, Academy of Management Review, vol. 20, no. 2, pp. 343-378, Apr. 1995. 
[2] P.G. Smith and D.G. Reinertsen, Developing products in half the time. New York: Van Nostrand Reinhold, 1998.

[3] H. Håkansson (Ed.), Industrial Technological Development, London: Croom Helm, 1987.

[4] K.B. Clark, "Project Scope and project performance: the effects of parts strategy and supplier involvement on product development”, Management Science, vol. 35, no. 10, pp. 1247-1263, 1989.

[5] A. Bonaccorsi, and A. Lipparini, "Strategic partnerships in new product development: an Italian case study”, Journal of Product Innovation Management, vol. 11, no. 1, pp. 134-145, 1994.

[6] G. L. Ragatz, R.B. Handfield and K.J. Petersen, "Benefits associated with supplier integration into product development under conditions of technology uncertainty”, Journal of Business Research, vol. 55, no. 5, pp. 389-400, 2002.

[7] M.A. Primo and S.D. Amundson, “An exploratory study of the effects of supplier relationships on new product development outcomes”, Journal of Operations Management, vol. 20, no.1, pp. 33-52, 2002.

[8] B.J. Zirger and J.L. Hartley, "The effect of acceleration techniques on product development time”, IEEE Transactions on Engineering Management, vol.43, no.2, pp. 143-152, 1997.

[9] J.L. Hartley, J.E. Meredith, D. McCutcheon and R.R. Kamath, "Suppliers' contributions to product development: an exploratory survey”, IEEE Transactions on Engineering Management, vol. 44, no. 3, pp.258-267, 1997.

[10] A. Takeishi, "Bridging inter- and intra-firm boundaries: management of supplier involvement in automobile product development”, Strategic Management Journal, vol. 22, no. 5, pp. 403-433, 2001.

[11] S.N. Wasti, and J.K. Liker, “Collaborating with suppliers in product development: a U.S. and Japan comparative study”, IEEE Transactions on Engineering Management, vol. 46, no. 4, pp. 444-461, 1999.

[12] R.R. Kamath and J.K. Liker, “A second look at Japanese product development”, Harvard Business Review, vol. 72, no. 6, pp. 154-170, 1994.

[13] J.Y.F. Wynstra and E. Ten Pierick, "Managing supplier involvement in product development: a portfolio approach”, European Journal of Purchasing and Supply Management, vol. 6, no. 1, pp. 49-57, 2000. 
[14] T.M. Laseter and K. Ramdas, "Product types and supplier roles in product development: an exploratory analysis”, IEEE Transactions on Engineering Management, vol. 49, no. 2, pp. 107-118, 2002.

[15] J.Y.F. Wynstra, M. Weggeman and A.J. van Weele, "Exploring purchasing integration in product development”, Industrial Marketing Management, vol. 32, no. 1, pp. 69-83, 2003.

[16] J.Y.F. Wynstra, B. Axelsson and A.J. van Weele, "Driving and enabling factors for purchasing involvement in product development”, European Journal of Purchasing and Supply Management, vol. 6, no. 2, pp. 129-141, 2000.

[17] J. Anklesaria and D.N. Burt, "Personal factors in the purchasing/engineering interface”, Journal of Purchasing and Materials Management, vol. 23, no.1, pp. 190202, 1987.

[18] S.P. Guy and B.G. Dale, "The role of purchasing in design: a study in the British defense

industry”, International Journal of Purchasing and Materials Management, vol. 29, no. 3, pp. 27-31, 1993.

[19] K. Atuahene-Gima, "Involving organizational buyers in new product development“, Industrial Marketing Management, vol. 24, no.3, pp. 215-226, 1995.

[21] K.M. Eisenhardt and B.N. Tabrizi, “Accelerating adaptive processes: product innovation in the global computer industry”, Administrative Science Quarterly, vol. 40, pp. 84-110, 1995.

[22] K.B. Clark and T. Fujimoto, Product development performance: strategy, organization and management in the world auto industry, Harvard Business School Press, Boston. 1991.

[23] C.M. Farr and W.A. Fischer, "Managing international high technology co-operative projects”, R\&D Management, vol. 22, no.1, pp. 77-95, 1992.

[24] M. Bruce, F. Leverick, D. Littler and D. Wilson, "Success factors for collaborative product development: a study of suppliers of information and communication technology”, R\&D Management, Vol. 25, pp. 33-44, 1995.

[25] R.B. Handfield, G.L. Ragatz, K.J. Petersen and R.M. Monczka, “Involving suppliers in new product development”, California Management Review, vol. 42, no. 1, pp. 5982, 1999.

[26] L.E. Gadde and I. Snehota, "Making the most of supplier relationships”, Industrial Marketing Management, vol. 29, no. 4, pp. 305-316, 2000. 
[27] J.Y.F. Wynstra, A.J. Van Weele and B. Axelsson, "Purchasing involvement in product development: a framework”, European Journal of Purchasing and Supply Management, vol. 5, no. 3-4, pp. 129-141, 1999.

[28] F.E.A. van Echtelt, J.Y.F. Wynstra, A.J. van Weele and G.M. Duysters, "Managing supplier involvement in new product development: a multiple-case study”, Journal of Product Innovation Management, forthcoming.

[29] L.M. Birou, The role of the buyer-supplier linkage in an integrated product development environment, unpublished $\mathrm{PhD}$ dissertation, Michigan State University, 1994.

[30] J.L. Hartley, Understanding supplier involvement in their customer's product development, unpublished PhD dissertation, Department of Quantitative Analysis and Operations Management, University of Cincinnati, 1994.

[31] G.L. Ragatz, R.B. Handfield and T.V. Scannell, "Success factors for integrating suppliers into product development”, Journal of Product Innovation Management, vol. 14, no.3, pp. 190-203, 1997.

[32] M. Sobrero and E.B. Roberts, "Strategic management of supplier-manufacturer relations in product development”, Research Policy, vol. 31, no. 1, pp. 159-182, 2002.

[33] R.M. Monczka, K.J. Petersen, R.B. Handfield and G. Ragatz, "Success factors in strategic supplier alliances: the buying company perspective”, Decision Sciences, vol. 29, no. 3, pp. 553-577, 1998.

[34] A. Bonaccorsi, "The external and internal integration of resources: evidence from a survey on procurement practices of medium and large manufacturing firms”, Conference Proceedings of the 6th IPSERA Annual Conference, Ischia, 24-26 March, pp. 1-20, 1997.

[35] R.M. Monczka, R.B. Handfield, T.V. Scannell, G.L. Ragatz and D.L. Frayer, New product development: strategies for supplier integration. Milwaukee: ASQ Quality Press, Milwaukee, 2000.

[36] C. Pralahad and G. Hamel, "The core competence of the corporation", Harvard Business Review, vol. 68, no. 3, pp. 79-91, 1990.

[37] H. Mintzberg, The structuring of organizations, Englewood Cliffs: Prentice-Hall, 1979.

[38] A. van de Ven and R. Drazin, "Alternative forms of fit in contingency theory”, Administrative Science Quarterly. vol. 30, no. 4, pp. 514-539, 1985. 
[39] A.J. van Weele, Purchasing management: analysis, planning and practice. Chapman \& Hall, London, 1999.

[40] D. Twigg, "Managing product development within a design chain”, International Journal of Operations and Production Management, vol. 18, no. 5, pp. 508-524, 1998.

[41] F. von Corswant and C. Tunälv, "Coordinating customers and proactive suppliers: a case study of supplier collaboration in product development”, Journal of Engineering and Technology Management, vol. 19, no. 3/4, pp. 249-261, 2002.

[42] L. Araujo, A. Dubois and L.E. Gadde, "Managing interfaces with suppliers", Industrial Marketing Management, vol. 28, no.5, pp. 497-506, 1999.

[43] M. Sobrero and E.B. Roberts, "The trade-off between efficiency and learning in inter-organizational relationships for product development”, Management Science, vol. 47, no. 4, pp. 493-511, 2001.

[44] R. Katz, "The Effects of group longevity on project communication and performance”, Administrative Science Quarterly, vol. 27, no.1, pp. 81-104, 1982.

[45] G.S. Lynn and R.R. Reilly, "Measuring team performance”, Research Technology Management, vol. 43, no. 2, pp. 48-56, 2000.

[46] A.E. Akgün and G.S. Lynn, “Antecedents and consequences of team stability on new product development performance”, Journal of Engineering Technology Management, vol. 19, no. 3/4, pp. 263-286, 2002.

[47] G. Spina, R. Verganti and G. Zotteri, "Factors influencing co-design adoption: drivers and internal consistency”, International Journal of Operations \& Production Management, vol. 22, no. 12, pp. 1354-1366, 2002.

[48] M.V. Tatikonda and S.R. Rosenthal, “Technology novelty, project complexity, and product development project execution success: a deeper look at task uncertainty in product innovation”, IEEE Transactions on Engineering Management, vol. 47, no. 1, pp. 74-87, 2000.

[49] R. Henderson and K. Clark, "Architectural innovation: the reconfiguration of existing product technologies and the failure of established firms”, Administrative Science Quarterly, vol. 35, no. 1, pp. 9-30, 1990.

[50] J.M. Utterback, "Innovation in industry and diffusion of technology”, Management Science, vol. 18, no. 3, pp. 658-662, 1971. 
[51] R.K. Moenaert and W.E. Souder, “An analysis of the use of extrafunctional information by R\&D and marketing personnel: review and model”, Journal of Product Innovation Management, vol. 7, no. 3, pp. 213-230, 1990.

[52] S. Dowlatshahi, "Purchasing's role in a concurrent engineering environment", International Journal of Operations and Production Management, vol. 18, no 2, pp. 143-167, 1992.

[53] R.K. Yin, Case study research: design and methods, 2nd edition, Thousand Oaks: Sage Publications, 1994.

[54] L.M. Birou and S.E. Fawcett, "Supplier involvement in integrated product development: a comparison of US and European practices”, International Journal of Physical Distribution and Logistics Management, vol. 24, no. 5, pp. 4-14, 1994.

[55] S.N. Wasti and J.K. Liker, "Risky business or competitive power? Supplier involvement in Japanese product design”, Journal of Product Innovation Management, vol. 14, no. 5, pp. 337-355, 1997.

[56] S. Evans and S. Jukes, "Improving co-development through process alignment”, International Journal of Operations and Production Management, vol.20, no. 8, pp. 979-988, 2000.

[57] A.H. van de Ven and D.L. Ferry, Measuring and assessing organizations, John Wiley \& Sons: New York, 1980.

[58] H. Praat and J. Krebbekx, “De nationale T\&U agenda: branche roadmaps voor de toeleveringsindustrie”, Berenschot, Press Conference ESEF, 2000.

[59] B. Glaser and A. Strauss, The discovery of grounded theory: strategies for qualitative research. Chicago: Aldine, 1967.

[60] S. Dowlatshahi, "Implementing early supplier involvement: a conceptual framework", International Journal of Operations and Production Management, vol. 18, no. 2, pp. 143-167, 1998.

[61] C. McDermott and R. Handfield, "Concurrent development and strategic outsourcing: do the

rules change in breakthrough innovation?”, Journal of High Technology Management Research, vol. 11, no. 1, pp. 35-57, 2000.

[62] W. van der Valk, Diagnosing supplier involvement in product development: a study on how to identify opportunities for improving supplier involvement. Unpublished Master's thesis, Department of Technology Management, Eindhoven (Netherlands): Eindhoven University of Technology, 2003. 
[63] W.E. Souder, J.D. Sherman and R. Davies-Cooper, "Environmental uncertainty, organizational integration, and new product development effectiveness: a test of contingency theory”, Journal of Product Innovation Management, vol. 15, no. 6, pp. 520-533, 1998. 
Appendix A: Overview questionnaire items / interview questions

\begin{tabular}{|c|c|c|}
\hline $\begin{array}{l}\text { Strategic } \\
\text { Management } \\
\text { Processes }\end{array}$ & $\begin{array}{l}\text { To what extent does your organization engage in ...? } \\
\text { (anchors: } 1 \text { : absent - 5: intelligent) }\end{array}$ & $\begin{array}{l}\text { Informants } \\
\text { Development Manager/ } \\
\text { Purchasing Manager }\end{array}$ \\
\hline SMP 1 & \multicolumn{2}{|l|}{$\begin{array}{ll}\text { 1. } & \text { Determining which technology development activities to outsource to suppliers. } \\
\text { 2. } & \text { Determining which product development activities to outsource to suppliers. } \\
\end{array}$} \\
\hline SMP 2 & \multicolumn{2}{|c|}{$\begin{array}{l}\text { 1. Formulating guidelines for internal departments on how to manage supplier involvement in the product development process (supplier selection instructions, } \\
\text { instructions for use of purchasing portfolio for a development project). } \\
\text { 2. Formulating guidelines for external suppliers on how to collaborate with your business unit in the product development process (instructions on project planning format } \\
\text { and project agreement elements, drawing standards). } \\
\text { 3. Communicating guidelines for internal departments on how to manage supplier involvement in the product development process (supplier selection instructions, } \\
\text { instructions for use of purchasing portfolio for a development project). } \\
\text { 4. Communicating guidelines for external suppliers on how to collaborate with your business unit in the product development process (instructions on project planning } \\
\text { format and project agreement elements, drawing standards). }\end{array}$} \\
\hline SMP 3 & \multicolumn{2}{|c|}{$\begin{array}{l}\text { 1. } \\
\text { 2. Scanning supplier markets for competitive developments (e.g. new entrants, regulations etc.). } \\
\text { 3. Scanning supplier markets for emergence of alternative technologies. } \\
\text { 4. } \\
\text { Involving suppliers in technology development activities for application in future product development projects. }\end{array}$} \\
\hline SMP 4 & \multicolumn{2}{|c|}{$\begin{array}{l}\text { 1. } \\
\text { 2. } \\
\text { Bre-qualifying suppliers. } \\
\text { 3. Evaluating innovation-related capabilities of suppliers (e.g. supplier engineering capabilities, investment by supplier in own R\&D). }\end{array}$} \\
\hline SMP 5 & \multicolumn{2}{|c|}{$\begin{array}{l}\text { 1. Applying technical standards being developed in supplier markets when designing new products. } \\
\text { 2. } \quad \text { Using elements (e.g. components, modules) already available in supplier markets when designing new products. } \\
\text { 3. Taking future supplier capabilities as a starting point in developing the Business Unit's technology roadmap. }\end{array}$} \\
\hline SMP 6 & \multicolumn{2}{|c|}{$\begin{array}{l}\text { 1. Influencing suppliers to focus their resources on specific technological areas, bringing this in line with your Business Unit's technology roadmap. } \\
\text { 2. Influencing suppliers to develop specific elements (e.g. components, modules), bringing this in line with your Business Unit's product roadmap. }\end{array}$} \\
\hline SMP 7 & \multicolumn{2}{|c|}{$\begin{array}{l}\text { 1. } \quad \text { Evaluating periodically suppliers' development performance to update the preferred supply base. } \\
\text { 2. }\end{array}$} \\
\hline
\end{tabular}




\begin{tabular}{|c|c|c|}
\hline $\begin{array}{l}\text { Operational } \\
\text { Management } \\
\text { Processes }\end{array}$ & $\begin{array}{l}\text { To what extent did/does the project team engage in ...? } \\
\text { (anchors: 1: absent - 5: intelligent) }\end{array}$ & $\begin{array}{l}\text { Informants Project } \\
\text { Leader/ Project Buyer* }\end{array}$ \\
\hline OMP 1 & $\begin{array}{l}\text { 1. Identifying upfront the different building blocks of the final product for which development activities were planned to be out } \\
\text { suppliers. } \\
\text { 2. Defining the preferred supplier development responsibility regarding the various building blocks of the final product (before }\end{array}$ & $\begin{array}{l}\text { itsourced to external } \\
\text { e the supplier is chosen). }\end{array}$ \\
\hline OMP 2 & $\begin{array}{l}\text { 1. Collecting suggestions from suppliers on alternative technologies or components during the product development process. } \\
\text { 2. Comparing alternative suppliers and their technologies or components for further evaluation during the project. }\end{array}$ & \\
\hline OMP 3 & $\begin{array}{l}\text { 1. Defining the criteria for selecting key suppliers for the development of different elements } \\
\text { 2. Choosing the actual supplier(s) to be involved }\end{array}$ & \\
\hline OMP 4 & $\begin{array}{l}\text { 1. Freezing the final degree of supplier development responsibility in the project when the supplier has been chosen. } \\
\text { 2. Planning in which project phase the suppliers' development activities must start. }\end{array}$ & \\
\hline OMP 5 & $\begin{array}{l}\text { 1. Determining upfront the specific operational performance targets with the supplier. } \\
\text { 2. Defining upfront the actual supplier development activities (e.g. proto-typing, tooling, testing) with the supplier in a project a } \\
\text { 3. Specifying contractual conditions regarding the collaboration in a formal contract. }\end{array}$ & agreement. \\
\hline OMP 6 & $\begin{array}{l}\text { 1. Determining upfront the communication structure between project team and individual first tier suppliers. } \\
\text { 2. Determining upfront the communication structure between the first tier suppliers and lower tier suppliers. } \\
\text { 3. Determining upfront the communication structure between different first tier suppliers. }\end{array}$ & \\
\hline OMP 7 & $\begin{array}{l}\text { 1. Coordinating supplier development activities between the project team and individual first tier suppliers. } \\
\text { 2. Coordinating supplier development activities between the first tier suppliers and lower tier suppliers. } \\
\text { 3. Coordinating supplier development activities between different first tier suppliers. }\end{array}$ & \\
\hline OMP 8 & $\begin{array}{l}\text { 1. Evaluating supplier designs regarding commercial aspects (e.g., component availability, lead-time costs). } \\
\text { 2. Evaluating supplier designs regarding technical aspects (e.g., quality, manufacturability, serviceability). } \\
\text { 3. Investigating possibilities for standardization of elements of the final product. }\end{array}$ & \\
\hline OMP 9 & $\begin{array}{l}\text { 1. Reviewing how suppliers performed in this development project. } \\
\text { 2. Feeding forward suppliers' development performance to be included in the preferred supplier list for future supplier selection }\end{array}$ & \\
\hline
\end{tabular}

*: Suppliers were asked similar questions. 


\begin{tabular}{|c|c|}
\hline $\begin{array}{l}\text { Strategic Business Unit } \\
\text { Enablers }\end{array}$ & $\begin{array}{l}\text { Question/Item 1: } \\
\text { To what extent does the following condition apply to your firm? } \\
\text { (anchors: 1: to a very small degree/not at all - 3: to a high degree) }\end{array}$ \\
\hline $\begin{array}{l}\text { Cross-functional } \\
\text { Integration }\end{array}$ & $\begin{array}{l}\text { 1. The technical expertise in the Purchasing department matches the way expertise in your R\&D/Engineering department is organized. } \\
\text { 2. The firm has assigned buyers with separate responsibilities, those with initial (tactical) responsibilities, (e.g. supplier selection in development projects) } \\
\text { and with operational responsibilities (e.g. ordering). } \\
\text { 3. The purchasing department is formally represented in the project team. }\end{array}$ \\
\hline $\begin{array}{l}\text { Human Resource Quality } \\
\text { (Experience) }\end{array}$ & $\begin{array}{l}\text { 1. Job-rotation of Purchasing employees to other departments is common practice. } \\
\text { 2. Job-rotation of R\&D employees to other departments is common practice. } \\
\text { 3. Technical experience gained in previous jobs is an important selection criterion for Purchasers to be employed in your organization. } \\
\text { 4. Commercial skills (e.g. value analysis and value engineering) developed in previous jobs are an important selection criterion for R\&D employees to be } \\
\text { employed in your organization. }\end{array}$ \\
\hline $\begin{array}{l}\text { Human Resource Quality } \\
\text { (Educational level) }\end{array}$ & $\begin{array}{l}\text { 1. The majority of the Purchasing employees have a higher educational degree. } \\
\text { 2. The majority of the R\&D employees have a higher educational degree. }\end{array}$ \\
\hline $\begin{array}{l}\text { Human Resource Quality } \\
\text { (Pro-activeness/Credibility) }\end{array}$ & $\begin{array}{l}\text { 1. The majority of the Purchasing employees are proactive in approaching R\&D people by offering help without being specifically asked. } \\
\text { 2. The majority of the R\&D employees are proactive in approaching Purchasing people by offering help without being specifically asked. }\end{array}$ \\
\hline
\end{tabular}

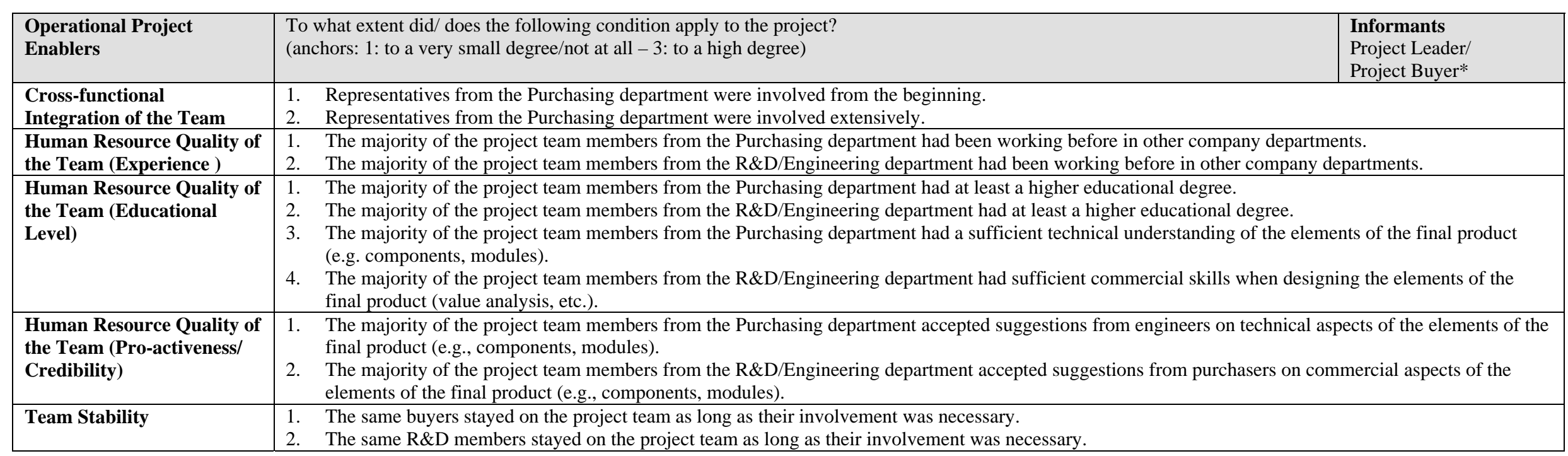

*: Suppliers were asked similar questions 


\begin{tabular}{|c|c|c|}
\hline $\begin{array}{l}\text { Strategic Business } \\
\text { Unit Drivers }\end{array}$ & $\begin{array}{l}\text { To what extent does the following condition apply to your firm? } \\
\text { (anchors: } 1 \text { : to a very small degree/not at all - 3: to a high degree) }\end{array}$ & $\begin{array}{l}\text { Informants Development Manager/ } \\
\text { Purchasing Manager }\end{array}$ \\
\hline Business Unit Size* & $\begin{array}{l}\text { 1. Number of employees } \\
\text { 2. Turnover/sales }\end{array}$ & \\
\hline Supplier Reliance & $\begin{array}{l}\text { 1. The firm buys a substantial amount of product and services from external suppliers relative to its total cost of goods sold. } \\
\text { 2. The firm is highly dependent on suppliers for innovation and improvement in its products and processes. }\end{array}$ & \\
\hline R\&D Reliance & $\begin{array}{l}\text { 1. The firm spends a substantial amount of time and money on Research and Development. } \\
\text { 2. The firm sees R\&D as a core process for achieving competitive advantage in the marketplace. }\end{array}$ & \\
\hline $\begin{array}{l}\text { Technological } \\
\text { Uncertainty }\end{array}$ & $\begin{array}{l}\text { 1. There is high rate of technological change in the external environment. } \\
\text { 2. The technological change in the external environment is very unpredictable. }\end{array}$ & \\
\hline $\begin{array}{l}\text { Operational Project } \\
\text { Drivers }\end{array}$ & $\begin{array}{l}\text { To what extent did/does the following condition apply to the project? } \\
\text { (anchors: 1: to a very small degree/not at all - 3: to a high degree) }\end{array}$ & Informants Project Leader \\
\hline $\begin{array}{l}\text { Degree of Project } \\
\text { Innovation }\end{array}$ & $\begin{array}{l}\text { 1. The elements of the final product at the start of the project as perceived by the project team were all new. } \\
\text { 2. The final product configuration at the start of the project as perceived by the project team was entirely new. } \\
\text { 3. The product technologies of the final product at the start of the project as perceived by the project team were all new. } \\
\text { 4. The manufacturing technologies of the final product at the start of the project as perceived by the project team were all new. }\end{array}$ & \\
\hline
\end{tabular}

*: Informants were asked to fill in the absolute numbers. The research team then classified firms as small (1), medium-sized (2) or large (3), based on standard classifications (OECD, EU).

\begin{tabular}{|c|c|c|}
\hline Results & & Informants Project Leader/Project Buyer* \\
\hline $\begin{array}{l}\text { Short-term Project Results } \\
\text { (anchors: 1: below target - 3: above } \\
\text { target) }\end{array}$ & & $\begin{array}{l}\text { Compared to the target set at the beginning, how did the selected project perform regarding Final Product Technical Performance? } \\
\text { Compared to the target set at the beginning, how did the selected project perform regarding Final Product Cost? } \\
\text { Compared to the target set at the beginning, how did the selected project perform regarding Development Cost? } \\
\text { Compared to the target set at the beginning, how did the selected project perform regarding Development Lead-Time? }\end{array}$ \\
\hline $\begin{array}{l}\text { Short-term Collaboration Results } \\
\text { (anchors: 1: below target - 3: above } \\
\text { target) }\end{array}$ & & $\begin{array}{l}\text { Compared to the target set at the beginning, how did the collaboration with supplier X perform in terms of part technical performance? } \\
\text { Compared to the target set at the beginning, how did the collaboration with supplier X perform in terms of part cost? } \\
\text { Compared to the target set at the beginning, how did the collaboration with supplier X perform in terms of part development time? } \\
\text { Compared to the target set at the beginning, how did the collaboration with supplier X perform in terms of part development cost? }\end{array}$ \\
\hline $\begin{array}{l}\text { Long-term results } \\
\text { (anchors: } 1 \text { : to a very small degree/not } \\
\text { at all - 3: to a high degree) }\end{array}$ & & $\begin{array}{l}\text { Collaboration will or has resulted in better alignment of technology roadmaps between your suppliers and your business unit. } \\
\text { Collaboration will or has resulted in improved access for your firm to suppliers' knowledge. } \\
\text { Collaboration will or has resulted adoption of solutions developed during the specific interaction with suppliers in other projects. } \\
\text { Collaboration will or has resulted in faster development speed in future collaboration. } \\
\text { Collaboration will or has resulted in lower development costs in future collaboration. } \\
\text { Collaboration will or has resulted in better performing designs in future collaboration. }\end{array}$ \\
\hline
\end{tabular}

* Suppliers were asked similar questions. 
Appendix B: Informants

\begin{tabular}{|c|c|c|c|}
\hline Firm & $\begin{array}{l}\text { General } \\
\text { interviews }\end{array}$ & Project & Project-specific informants \\
\hline \multirow[t]{2}{*}{$\begin{array}{l}\text { Philips } \\
\text { Domestic } \\
\text { Appliances } \\
\text { (DAP) }\end{array}$} & \multirow[t]{2}{*}{$\begin{array}{l}\text { Development } \\
\text { Managers } \\
\text { (Floorcare, } \\
\text { Beverages); } \\
\text { Purchasing } \\
\text { Manager }\end{array}$} & Vacuum cleaner & $\begin{array}{l}\text { Internal: } \\
\text { Project Leader; Strategic Buyer Floorcare; } \\
\text { Mechanical Engineer; Project Purchaser } \\
\text { Supplier A: } \\
\text { Acquisition \& Advice }\end{array}$ \\
\hline & & Coffee Machine & $\begin{array}{l}\text { Internal: } \\
\text { Project Purchaser; Project Leader } \\
\text { Supplier B: } \\
\text { Sales Manager; Technical Project Leader }\end{array}$ \\
\hline \multirow[t]{2}{*}{$\begin{array}{l}\text { PANalytical } \\
\text { (PAN) }\end{array}$} & \multirow[t]{2}{*}{$\begin{array}{l}\text { Development } \\
\text { Manager; } \\
\text { Purchasing } \\
\text { Manager }\end{array}$} & $\begin{array}{l}\text { Energy dispersive } \\
\text { spectrometer }\end{array}$ & $\begin{array}{l}\text { Internal: } \\
\text { Electrical Purchaser; Electrical Engineer; } \\
\text { Mechanical Engineer; Project Purchaser; Initial } \\
\text { Purchaser } \\
\text { Project Purchaser; Project Leader; Software } \\
\text { Development; Software Development Manager; } \\
\text { Project Leader } \\
\text { Supplier C: } \\
\text { Director Benelux; Delegated Administrator } \\
\text { Supplier D* } \\
\text { Supplier E: } \\
\text { Head Engineering Department } \\
\text { Supplier F: } \\
\text { Senior Consultant/ Project Manager; Account } \\
\text { Manager }\end{array}$ \\
\hline & & Sample Changer & $\begin{array}{l}\text { Internal: } \\
\text { Mechanical Engineer; Project Purchaser; } \\
\text { Electrical Engineer PCB; } \\
\text { Electrical Engineer cables and wiring; Project } \\
\text { Leader } \\
\text { Supplier G: } \\
\text { Head Automation Department; Project Leader }\end{array}$ \\
\hline \multirow[t]{2}{*}{$\begin{array}{l}\text { Boon Edam } \\
\text { (BED) }\end{array}$} & \multirow[t]{2}{*}{$\begin{array}{l}\text { R\&D } \\
\text { Manager; } \\
\text { Purchasing } \\
\text { Manager }\end{array}$} & $\begin{array}{l}\text { High-speed } \\
\text { safety gate }\end{array}$ & $\begin{array}{l}\text { Internal: } \\
\text { Project Purchaser; Mechanical Constructor; } \\
\text { Project Leader } \\
\text { Supplier H: } \\
\text { Technical Support Engineer } \\
\text { Area Sales Manager } \\
\text { Supplier I: } \\
\text { Account Manager; Constructor }\end{array}$ \\
\hline & & $\begin{array}{l}\text { High Capacity } \\
\text { revolving door }\end{array}$ & $\begin{array}{l}\text { Internal: Mechanical Constructor; Project Leader } \\
\text { Supplier J: Director; Engineer } \\
\text { Supplier K: Account Manager; Engineer }\end{array}$ \\
\hline \multirow[t]{2}{*}{$\begin{array}{l}\text { HJ Heinz } \\
\text { (HJH) }\end{array}$} & \multirow{2}{*}{$\begin{array}{l}\text { NPD } \\
\text { Manager HJ } \\
\text { Heinz } \\
\text { Europe; } \\
\text { European } \\
\text { Purchasing } \\
\text { Manager Co- } \\
\text { pack }\end{array}$} & $\begin{array}{l}\text { Carbonated Soda } \\
\text { Drink Project }\end{array}$ & $\begin{array}{l}\text { Internal: } \\
\text { Marketing/ Project Leader; Project Purchaser } \\
\text { Supplier L: } \\
\text { Technical Support Manager }\end{array}$ \\
\hline & & $\begin{array}{l}\text { Fruit-flavored } \\
\text { sprinkles }\end{array}$ & $\begin{array}{l}\text { Internal: } \\
\text { Development/ Project Leader; Project Purchaser } \\
\text { Supplier M: } \\
\text { Product Developer }\end{array}$ \\
\hline
\end{tabular}

*: No company access. As already three suppliers shared their opinions and experiences on the customer's way of managing supplier involvement, we had sufficient (and convergent) data for the overall project case. 
Figure 1: Analysis Framework. Adapted from: Van Echtelt et al. [28]

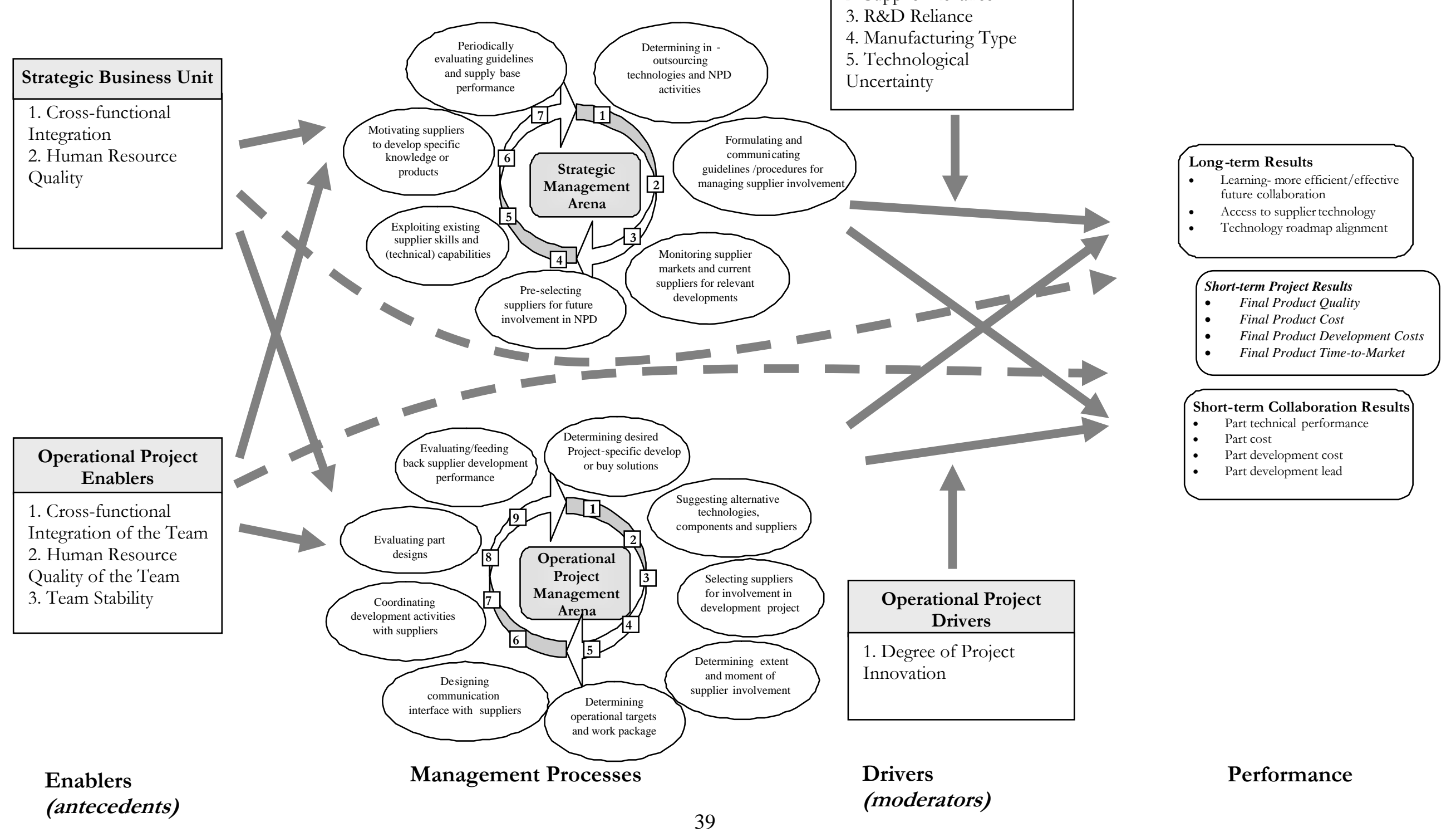


Figure 2: Plotting the case study findings

\begin{tabular}{|c|c|c|c|c|}
\hline \multirow{4}{*}{ Performance } & $\begin{array}{c}\text { Better than } \\
\text { predicted }\end{array}$ & SG & CM & \\
\cline { 2 - 5 } & As predicted & RD & VC & SD \\
\cline { 2 - 5 } & $\begin{array}{c}\text { Worse than } \\
\text { predicted }\end{array}$ & & & SM, SC, FS \\
\cline { 2 - 5 } & \multicolumn{2}{|c|}{ Low } & Neutral & High \\
\cline { 2 - 5 } & \multicolumn{2}{|c|}{ Presence of taxing conditions } \\
\hline
\end{tabular}


TABLE I: Overview of case studies

\begin{tabular}{|l|l|l|l|l|}
\hline & Projects & $\begin{array}{l}\text { Degree of } \\
\text { innovation }\end{array}$ & Parts developed & Suppliers \\
\hline $\begin{array}{l}\text { Philips Domestic } \\
\text { Appliances (DAP) }\end{array}$ & Vacuum cleaner & Medium-High & External fragrance module & A \\
\cline { 2 - 5 } & Coffee machine & Low-Medium & Boiler system & B \\
\hline PANalytical (PAN) & Spectrometer & High & $\begin{array}{l}\text { Detector system, high voltage } \\
\text { generator, metal casing and } \\
\text { mechatronics assembly software } \\
\text { package }\end{array}$ & C, D, E, F \\
& Sample changer & Low & $\begin{array}{l}\text { Three-dimensional straight-line guide } \\
\text { way }\end{array}$ & G \\
\hline Boon Edam (BED) & Speed gate & High & $\begin{array}{l}\text { Sensor-package + control box, } \\
\text { Steel gate construction }\end{array}$ & H, I \\
\cline { 2 - 6 } & Revolving door & Low & $\begin{array}{l}\text { Steel centre column and } \\
\text { Stainless steel centre column }\end{array}$ & J, K \\
\hline H.J. Heinz (HJH) & $\begin{array}{l}\text { Carbonated soda } \\
\text { drink }\end{array}$ & High & Bottle filling production supplier & $\mathbf{L}$ \\
\cline { 2 - 6 } & Fruit sprinkles & Low & $\begin{array}{l}\text { Process supplier for fruit sprinkles } \\
\text { production }\end{array}$ & $\mathbf{M}$ \\
\hline
\end{tabular}

TABLE II: Validity of the study

\begin{tabular}{|c|c|}
\hline Type of validity & Methods of addressing this in the case studies \\
\hline $\begin{array}{l}\text { Construct validity: } \\
\text { "establishment of correct operational } \\
\text { measures for the concepts being studied" }\end{array}$ & $\begin{array}{l}\text { - } \text { Triangulation of questionnaire and interview data } \\
\text { - } \quad \text { Triangulation of multiple informants: different } \\
\text { internal representatives, supplier representatives } \\
\text { - All informants received draft versions of the } \\
\text { interview report for comments } \\
\text { - Draft versions of the complete case report were } \\
\text { verified with at least one key informant from each } \\
\text { buying firm } \\
\text { - Three research team members gave input during } \\
\text { data collection and analysis } \\
\text { - Result: emergent explanations adjusted and } \\
\text { expanded; participants agreed to the interpretations }\end{array}$ \\
\hline $\begin{array}{l}\text { Internal validity: } \\
\text { “establishing casual relationships whereby } \\
\text { certain conditions are shown to lead to other } \\
\text { conditions, as distinguished from spurious } \\
\text { relationships” }\end{array}$ & $\begin{array}{l}\text { - Use of theoretical model / analysis framework } \\
\text { - Result: relationships between the different variables } \\
\text { from the analysis framework identified and } \\
\text { substantiated }\end{array}$ \\
\hline $\begin{array}{l}\text { External validity: } \\
\text { "establishing a domain in which the study's } \\
\text { findings can be generalized" }\end{array}$ & $\begin{array}{l}\text { - Theoretical sampling of cases at two levels of } \\
\text { analysis: strategic (firm) and operational (project) } \\
\text { level } \\
\text { - } \\
\text { Result: revised framework applicable to different } \\
\text { types of firms and projects }\end{array}$ \\
\hline $\begin{array}{l}\text { Reliability: } \\
\text { "demonstrating that the operations of a study } \\
\text { can be repeated with the same results" }\end{array}$ & $\begin{array}{l}\text { - Development of questionnaire } \\
\text { - } \quad \text { Development of case protocol } \\
\text { - } \quad \text { Result: methodology transparent and repeatable }\end{array}$ \\
\hline
\end{tabular}

Based on: Yin [53]. 
TABLE III: Overview average scores drivers, enablers, processes and results

\begin{tabular}{|c|c|c|c|c|c|c|c|c|c|c|}
\hline Companies & Projects & $\begin{array}{l}\text { Operational } \\
\text { Project } \\
\text { Drivers } \wedge\end{array}$ & $\begin{array}{l}\text { Strategic } \\
\text { Business } \\
\text { Unit } \\
\text { Drivers } \\
\wedge \wedge\end{array}$ & $\begin{array}{l}\text { Operational } \\
\text { Project } \\
\text { Enablers^ }\end{array}$ & $\begin{array}{l}\text { Strategic } \\
\text { Business } \\
\text { Unit } \\
\text { Enablers } \\
\wedge \wedge\end{array}$ & 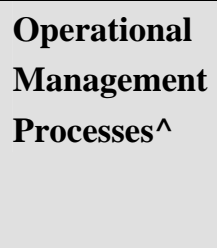 & $\begin{array}{l}\text { Strategic } \\
\text { Management } \\
\text { Processes } \wedge\end{array}$ & 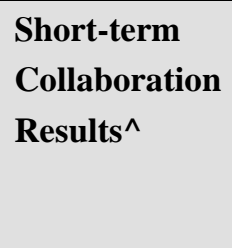 & $\begin{array}{l}\text { Short- } \\
\text { term } \\
\text { Project } \\
\text { Results } \\
\wedge\end{array}$ & $\begin{array}{l}\text { Long-term } \\
\text { Results } \wedge \wedge\end{array}$ \\
\hline \multirow[t]{2}{*}{ DAP } & $\begin{array}{l}\text { Vacuum cleaner } \\
\text { (VC) }\end{array}$ & 3.0 & \multirow{2}{*}{2.3} & 2.7 & \multirow{2}{*}{2.3} & 2.7 & \multirow{2}{*}{3.6} & 2.3 & 2.5 & 2.5 \\
\hline & $\begin{array}{l}\text { Coffee machine } \\
\text { (CM) }\end{array}$ & 2.0 & & 2.7 & & 2.8 & & 2.0 & 2.0 & 2.3 \\
\hline \multirow[t]{2}{*}{ PAN } & $\begin{array}{l}\text { Spectrometer } \\
\text { (SM) }\end{array}$ & 3.0 & \multirow{2}{*}{3.0} & 2.3 & \multirow{2}{*}{2.3} & 2.9 & \multirow{2}{*}{2.9} & 1.6 & 1.3 & 1.7 \\
\hline & $\begin{array}{l}\text { Sample-changer } \\
\text { (SC) }\end{array}$ & 1.0 & & 2.0 & & 2.7 & & 2.0 & 2.3 & 1.3 \\
\hline \multirow[t]{2}{*}{ BED } & $\begin{array}{l}\text { Speed gate } \\
\text { (SG) }\end{array}$ & 3.0 & \multirow{2}{*}{1.6} & 2.0 & \multirow{2}{*}{1.5} & 2.1 & \multirow{2}{*}{2.1} & 2.1 & 2.0 & 1.8 \\
\hline & $\begin{array}{l}\text { Revolving door } \\
\text { (RD) }\end{array}$ & 1.0 & & 1.5 & & 2.0 & & 2.0 & 1.8 & 1.3 \\
\hline \multirow[t]{2}{*}{ HJH } & $\begin{array}{l}\text { Carbonated } \\
\text { soda drink (SD) }\end{array}$ & 3.0 & \multirow{2}{*}{3.0} & 2.7 & \multirow{2}{*}{2.6} & 3.8 & \multirow{2}{*}{4.3} & 2.3 & 2.3 & 2.3 \\
\hline & $\begin{array}{l}\text { Fruit sprinkles } \\
\text { (FS) }\end{array}$ & 1.0 & & 2.7 & & 4.0 & & 2.0 & 2.0 & 2.0 \\
\hline
\end{tabular}

* Scale: 1-low; 2-medium; 3-high. For enablers: further breakdowns provided in Table VI.

** Scale: 1-Absent: the process is not carried out; 2-Reactive: the process is carried out in an ad-hoc way, as a result of occurring events; 3-Pro-active: the process is carried out following an implicit structure or set of activities; 4-Systematic: as in 'pro-active', but supported by systems, procedures and guidelines: 5-Intelligent: as in 'systematic', but able to critically review the processes in the light of the situation and to adapt (incidentally or more permanently) when necessary. Breakdowns provided in Table V.

\# Scale: 1-below target; 2-on target; 3-above target. Breakdowns provided in Table IV.

\#\# Scale: 1: to a very small degree/not at all; 2- to some degree; 3: to a high degree. Breakdowns provided in Table IV.

$\wedge$ : Informants: project leader and project buyer. $\wedge$ : Informants: R\&D manager and Purchasing manager. 
TABLE IV: Project performance: short-term and long-term results

\begin{tabular}{|c|c|c|c|c|c|c|c|c|c|c|c|c|c|c|c|}
\hline \multirow[b]{2}{*}{ Firm } & \multirow[b]{2}{*}{ Project } & \multicolumn{5}{|c|}{$\begin{array}{l}\text { Short-term Collaboration } \\
\text { Results^} \wedge \\
\end{array}$} & \multicolumn{5}{|c|}{ Short-Term Project Results $\wedge$} & \multicolumn{4}{|c|}{$\begin{array}{l}\text { Long-term Collaboration } \\
\text { Results } \wedge \wedge\end{array}$} \\
\hline & & 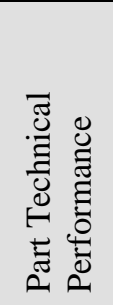 & 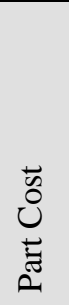 & 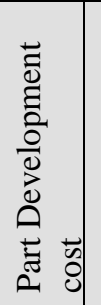 & 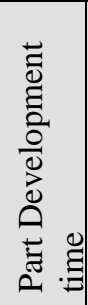 & 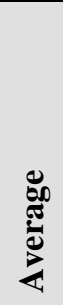 & 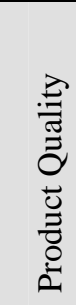 & $\begin{array}{l}\tilde{w} \\
0 \\
\tilde{U} \\
ت \\
0 \\
0 \\
0\end{array}$ & 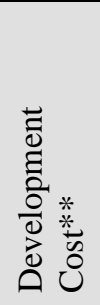 & 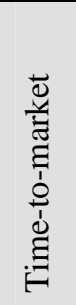 & 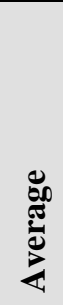 & 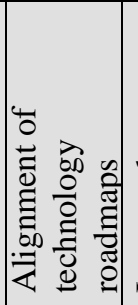 & 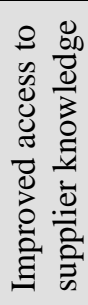 & 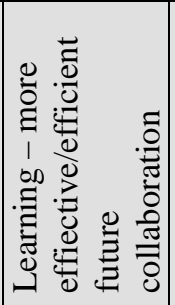 & 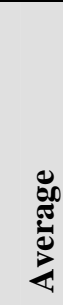 \\
\hline \multirow{2}{*}{ DAP } & Vacuum cleaner $(\mathrm{VC})$ & 3.0 & 2.0 & 2.0 & 2.0 & 2.3 & 3.0 & 2.0 & 3.0 & 2.0 & 2.5 & 1.0 & 3.0 & 3.0 & 2.5 \\
\hline & Coffee machine (CM) & 2.0 & 2.0 & 2.0 & 2.0 & 2.0 & 2.0 & 2.0 & 2.0 & 2.0 & 2.0 & 2.0 & 2.0 & 3.0 & 2.3 \\
\hline \multirow{2}{*}{ PAN } & Spectrometer (SM)* & 1.75 & 1.5 & 1.5 & 1.5 & 1.6 & 2.0 & 1.0 & 1.0 & 1.0 & 1.3 & 1.0 & 2.0 & 2.0 & 1.7 \\
\hline & Sample-changer (SC) & 2.0 & 2.0 & 2.0 & 2.0 & 2.0 & 2.0 & 2.0 & 2.0 & 3.0 & 2.3 & 1.0 & 1.0 & 2.0 & 1.3 \\
\hline \multirow{2}{*}{ BED } & Speed gate (SG)* & 2.5 & 2.0 & 2.0 & 2.0 & 2.1 & 3.0 & 1.0 & 2.0 & 2.0 & 2.0 & 1.5 & 2.5 & 1.5 & 1.8 \\
\hline & Revolving door (RD)* & 2.0 & 2.0 & 2.0 & 2.0 & 2.0 & 2.0 & 1.0 & 2.0 & 2.0 & 1.8 & 1.0 & 1.0 & 2.0 & 1.3 \\
\hline
\end{tabular}

Informants: project leader and project buyer.

$\wedge$ : Anchors: 1 : worse than target -3 : better than target. $\wedge$ : Anchors: 1 : to a very small degree/not at all -3 : to a high degree.

*: This project included more than one supplier (see Table 1 ), and the scores refer to averages for these suppliers.

** The reported results on development costs are most likely not the total costs. The governance costs in terms of contracting and coordinating development activities concerning different departments are certainly higher than expected but are not quantified or quantifiable. 
TABLE V: Managerial processes (anchors: 1: absent - 5: intelligent)

\begin{tabular}{|c|c|c|c|c|c|c|c|c|}
\hline & \multicolumn{2}{|c|}{ DAP } & \multicolumn{2}{|c|}{ PAN } & \multicolumn{2}{|c|}{ BED } & \multicolumn{2}{|c|}{ HJH } \\
\hline Operational Management Processes* & VC & $\mathbf{C M}$ & SM & SC & SG & $\mathbf{R D}$ & SD & FS \\
\hline Determining desired develop \& buy solutions & 4 & 4 & 4 & 4 & 2 & 2 & 4 & 4 \\
\hline $\begin{array}{l}\text { Suggesting alternative } \\
\text { technologies/components/suppliers }\end{array}$ & 2 & 2 & 3 & 2 & 3 & 1 & 4 & 3 \\
\hline Selecting suppliers for involvement in a project & 2 & 2 & 3 & 1 & 2 & 2 & 3 & 3 \\
\hline Determining extent and timing of involvement & 2 & 2 & 3 & 3 & 2 & 2 & 4 & 3 \\
\hline $\begin{array}{l}\text { Determining development operational targets and } \\
\text { work package }\end{array}$ & 3 & 4 & 3 & 3 & 3 & 3 & 4 & 4 \\
\hline Designing communication interface & 3 & 3 & 3 & 3 & 1 & 1 & 3 & 5 \\
\hline Coordinating suppliers' development activities & 2 & 3 & 2 & 2 & 2 & 2 & 4 & 4 \\
\hline Evaluating part designs & 4 & 4 & 4 & 4 & 3 & 3 & 3 & 4 \\
\hline Evaluating supplier development performance & 2 & 1 & 1 & 2 & 1 & 2 & 5 & 5 \\
\hline Average Operational Management Processes & 2.7 & 2.8 & 2.9 & 2.7 & 2.1 & 2.0 & 3.8 & 4.0 \\
\hline Strategic Management Processes** & \multicolumn{2}{|c|}{ DAP } & \multicolumn{2}{|c|}{ PAN } & \multicolumn{2}{|c|}{ BED } & \multicolumn{2}{|c|}{ HJH } \\
\hline Determining technology in-outsourcing policy & \multicolumn{2}{|c|}{4} & \multicolumn{2}{|c|}{3} & \multicolumn{2}{|c|}{2} & \multicolumn{2}{|c|}{5} \\
\hline $\begin{array}{l}\text { Formulating and communicating guidelines for } \\
\text { managing supplier involvement }\end{array}$ & \multicolumn{2}{|c|}{3} & \multicolumn{2}{|c|}{3} & \multicolumn{2}{|c|}{1} & \multicolumn{2}{|c|}{5} \\
\hline $\begin{array}{l}\text { Monitoring markets and current suppliers for relevant } \\
\text { developments }\end{array}$ & \multicolumn{2}{|c|}{3} & \multicolumn{2}{|c|}{3} & \multicolumn{2}{|c|}{3} & \multicolumn{2}{|c|}{4} \\
\hline Pre-selecting suppliers for involvement in future NPD & \multicolumn{2}{|c|}{4} & \multicolumn{2}{|c|}{3} & \multicolumn{2}{|c|}{3} & \multicolumn{2}{|c|}{4} \\
\hline $\begin{array}{l}\text { Exploiting existing suppliers’ skills and (technical) } \\
\text { capabilities }\end{array}$ & \multicolumn{2}{|c|}{4} & \multicolumn{2}{|c|}{3} & \multicolumn{2}{|c|}{2} & \multicolumn{2}{|c|}{3} \\
\hline Motivating suppliers for developing skills or products & \multicolumn{2}{|c|}{3} & \multicolumn{2}{|c|}{3} & \multicolumn{2}{|c|}{3} & \multicolumn{2}{|c|}{4} \\
\hline $\begin{array}{l}\text { Periodically evaluating guidelines and supply base } \\
\text { performance }\end{array}$ & \multicolumn{2}{|c|}{4} & \multicolumn{2}{|c|}{2} & & & & \\
\hline Average Strategic Management Processes & & & & & & & & 3 \\
\hline
\end{tabular}

Informants: *: R\&D project leader and project buyer. **: R\&D/Development manager and Purchasing manager.

TABLE VI: Enablers (anchors: 1: low - 3: high)

\begin{tabular}{|c|c|c|c|c|c|c|c|c|}
\hline \multirow{2}{*}{ Firm } & \multirow{2}{*}{ Project } & \multicolumn{4}{|c|}{ Operational Project Enablers* } & \multicolumn{3}{|c|}{$\begin{array}{l}\text { Strategic Business } \\
\text { Enablers** }\end{array}$} \\
\hline & & 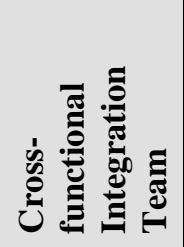 & 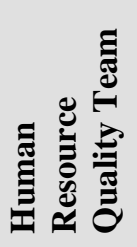 & 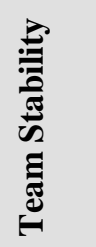 & 范 & 氖.气 & 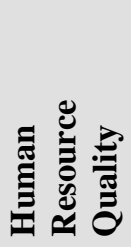 & 范 \\
\hline \multirow[t]{2}{*}{ DAP } & $\begin{array}{l}\text { Vacuum } \\
\text { cleaner }\end{array}$ & 2.8 & 2.4 & 3.0 & 2.7 & \multirow[t]{2}{*}{2.5} & \multirow[t]{2}{*}{2.1} & \multirow[t]{2}{*}{2.3} \\
\hline & $\begin{array}{c}\text { Coffee } \\
\text { machine }\end{array}$ & 2.6 & 2.2 & 2.3 & 2.7 & & & \\
\hline \multirow[t]{2}{*}{ PAN } & Spectrometer & 2.5 & 1.9 & 2.5 & 2.3 & \multirow[t]{2}{*}{2.7} & \multirow[t]{2}{*}{1.9} & \multirow[t]{2}{*}{2.3} \\
\hline & $\begin{array}{l}\text { Sample } \\
\text { changer }\end{array}$ & 1.9 & 2.0 & 2.0 & 2.0 & & & \\
\hline \multirow[t]{2}{*}{ BED } & Speed gate & 2.1 & 1.9 & 2.0 & 2.0 & \multirow[t]{2}{*}{1.7} & \multirow[t]{2}{*}{1.2} & \multirow[t]{2}{*}{1.5} \\
\hline & $\begin{array}{l}\text { Revolving } \\
\text { Door }\end{array}$ & 1.6 & 1.4 & 1.5 & 1.5 & & & \\
\hline \multirow[t]{2}{*}{ HJH } & $\begin{array}{l}\text { Carbonated } \\
\text { soda drink }\end{array}$ & 3 & 2.1 & 3 & 2.7 & \multirow[t]{2}{*}{2.7} & \multirow[t]{2}{*}{2.5} & \multirow[t]{2}{*}{2.6} \\
\hline & $\begin{array}{c}\text { Fruit } \\
\text { sprinkles }\end{array}$ & 2.8 & 2.3 & 3 & 2.7 & & & \\
\hline
\end{tabular}


TABLE VII: Highly innovative versus less innovative projects

\begin{tabular}{|c|c|c|c|c|c|c|c|c|c|c|}
\hline & $\begin{array}{l}\text { DAP } \\
\text { VC }\end{array}$ & $\begin{array}{l}\text { PAN } \\
\text { SM }\end{array}$ & $\begin{array}{l}\text { BED } \\
\text { SG }\end{array}$ & $\begin{array}{l}\text { HJH } \\
\text { SD }\end{array}$ & $\begin{array}{l}\text { Ave- } \\
\text { rage }\end{array}$ & $\begin{array}{l}\text { DAP } \\
\text { CM }\end{array}$ & $\begin{array}{l}\text { PAN } \\
\text { SC }\end{array}$ & $\begin{array}{l}\text { BED } \\
\text { RD }\end{array}$ & $\begin{array}{l}\text { HJH } \\
\text { FS }\end{array}$ & $\begin{array}{l}\text { Ave- } \\
\text { rage }\end{array}$ \\
\hline & \multicolumn{4}{|c|}{$\begin{array}{l}\text { High degree of project } \\
\text { innovation }\end{array}$} & & \multicolumn{4}{|c|}{$\begin{array}{l}\text { Low degree of project } \\
\text { innovation }\end{array}$} & \\
\hline $\begin{array}{l}\text { Average score: } \\
\text { Short-term Project } \\
\text { Results } \\
\text { (scale: } 1-3)\end{array}$ & 2.5 & 1.3 & 2.0 & 2.3 & 2.0 & 2.0 & 2.3 & 2.0 & 2.0 & 2.1 \\
\hline $\begin{array}{l}\text { Average score: } \\
\text { Operational } \\
\text { Management Processes } \\
\text { (scale: } 1-5 \text { ) }\end{array}$ & 2.7 & 2.9 & 2.1 & 3.8 & 2.9 & 2.8 & 2.7 & 2.0 & 4.0 & 2.9 \\
\hline $\begin{array}{l}\text { Average score: } \\
\text { Planning Processes } \\
\text { (OMP 1-6) } \\
\text { (scale: } 1-5 \text { ) }\end{array}$ & 2.7 & 3.2 & 2.2 & 3.7 & 3.0 & 2.7 & 2.7 & 1.8 & 3.8 & 2.8 \\
\hline $\begin{array}{l}\text { OMP1: Determining } \\
\text { project-specific develop- } \\
\text { or-buy solutions }\end{array}$ & 4 & 4 & 2 & 4 & 3.5 & 4 & 4 & 2 & 4 & 3.5 \\
\hline $\begin{array}{l}\text { OMP2: Suggesting } \\
\text { alternative technologies/ } \\
\text { components/suppliers }\end{array}$ & 2 & 3 & 3 & 4 & 3.0 & 1 & 2 & 1 & 3 & 1.8 \\
\hline $\begin{array}{l}\text { OMP3: Selecting suppliers } \\
\text { for involvement in NPD } \\
\text { project }\end{array}$ & 2 & 3 & 2 & 3 & 2.5 & 2 & 1 & 2 & 3 & 2.0 \\
\hline $\begin{array}{l}\text { OMP4: Determining } \\
\text { extent and moment of } \\
\text { supplier involvement }\end{array}$ & 2 & 3 & 2 & 4 & 2.8 & 2 & 3 & 2 & 4 & 2.8 \\
\hline $\begin{array}{l}\text { OMP5: Determining } \\
\text { operational targets and } \\
\text { work package }\end{array}$ & 3 & 3 & 3 & 4 & 3.3 & 4 & 3 & 3 & 4 & 3.5 \\
\hline $\begin{array}{l}\text { OMP6: Designing } \\
\text { communication interface } \\
\text { with suppliers }\end{array}$ & 3 & 3 & 1 & 3 & 2.5 & 3 & 3 & 1 & 5 & 3.0 \\
\hline
\end{tabular}




\section{Publications in the Report Series Research ${ }^{*}$ in Management}

\section{ERIM Research Program: "Business Processes, Logistics and Information Systems"}

2007

India: a Case of Fragile Wireless Service and Technology Adoption?

L-F Pau and J. Motiwalla

ERS-2007-011-LIS

http://hdl.handle.net/1765/9043

Some Comments on the Question Whether Co-occurrence Data Should Be Normalized

Ludo Waltman and Nees Jan van Eck

ERS-2007-017-LIS

http://hdl.handle.net/1765/9401

Extended Producer Responsibility in the Aviation Sector

Marisa P. de Brito, Erwin A. van der Laan and Brijan D. Irion

ERS-2007-025-LIS

http://hdl.handle.net/1765/10068

Logistics Information and Knowledge Management Issues in Humanitarian Aid Organizations

Erwin A. van der Laan, Marisa P. de Brito and S. Vermaesen

ERS-2007-026-LIS

http://hdl.handle.net/1765/10071

Bibliometric Mapping of the Computational Intelligence Field

Nees Jan van Eck and Ludo Waltman

ERS-2007-027-LIS

http://hdl.handle.net/1765/10073

Approximating the Randomized Hitting Time Distribution of a Non-stationary Gamma Process

J.B.G. Frenk and R.P. Nicolai

ERS-2007-031-LIS

http://hdl.handle.net/1765/10149

Application of a General Risk Management Model to Portfolio Optimization Problems with Elliptical Distributed Returns for Risk Neutral and Risk Averse Decision Makers

Bahar Kaynar, S. Ilker Birbil and J.B.G. Frenk

ERS-2007-032-LIS

http://hdl.handle.net/1765/10151

Optimal Zone Boundaries for Two-class-based Compact 3D AS/RS

Yugang Yu and M.B.M. de Koster

ERS-2007-034-LIS

http://hdl.handle.net/1765/10180

Portfolios of Exchange Relationships: An Empirical Investigation of an Online Marketplace for IT Services

Uladzimir Radkevitch, Eric van Heck and Otto Koppius

ERS-2007-035-LIS

http://hdl.handle.net/1765/10072

From Closed-Loop to Sustainable Supply Chains: The WEEE case

J. Quariguasi Frota Neto, G. Walther, J.Bloemhof, J.A.E.E van Nunen and T.Spengler

ERS-2007-036-LIS

http://hdl.handle.net/1765/10176 
A Methodology for Assessing Eco-Efficiency in Logistics Networks

J. Quariguasi Frota Neto, G. Walther, J.Bloemhof, J.A.E.E van Nunen and T.Spengler

ERS-2007-037-LIS

http://hdl.handle.net/1765/10177

Strategic and Operational Management of Supplier Involvement in New Product Development: a Contingency Perspective Ferrie E.A. van Echtelt, Finn Wynstra and Arjan J. van Weele

ERS-2007-040-LIS

How Will Online Affiliate Marketing Networks Impact Search Engine Rankings?

David Janssen and Eric van Heck

ERS-2007-042-LIS

Modelling and Optimizing Imperfect Maintenance of Coatings on Steel Structures

R.P. Nicolai, J.B.G. Frenk and R. Dekker

ERS-2007-043-LIS

Human Knowledge Resources and Interorganizational Systems

Mohammed Ibrahim, Pieter Ribbers and Bert Bettonvil

ERS-2007-046-LIS

Is Management Interdisciplinary? The evolution of management as an interdisciplinary field of science and education in the Netherlands

Peter van Baalen and Luchien Karsten

ERS-2007-047-LIS

* A complete overview of the ERIM Report Series Research in Management: https://ep.eur.nl/handle/1765/1

ERIM Research Programs:

LIS Business Processes, Logistics and Information Systems

ORG Organizing for Performance

MKT Marketing

F\&A Finance and Accounting

STR Strategy and Entrepreneurship 